\title{
Comparative analysis of the acute response of the trout, 0 . mykiss, head kidney to in vivo challenge with virulent and attenuated infectious hematopoietic necrosis virus and LPS-induced inflammation
}

\author{
Simon MacKenzie ${ }^{*+1}$, Joan C Balasch ${ }^{\dagger 1}$, Beatriz Novoa ${ }^{2}$, Laia Ribas ${ }^{3}$, \\ Nerea Roher ${ }^{4}$, Aleksei Krasnov ${ }^{5}$ and Antonio Figueras ${ }^{2}$
}

Address: ${ }^{1}$ Unitat de Fisiologia Animal, Departament de Biologia Cellular, de Fisiologia i d'Immunologia, Universitat Autonoma de Barcelona (UAB), Barcelona, Spain, ${ }^{2}$ Instituto de Investigaciones Marinas, CSIC, Vigo, Spain, ${ }^{3}$ Imperial College Faculty of Medicine, Dpt of Infectious Disease Epidemiology, London, UK, ${ }^{4}$ Departament de Fisiologia, Facultat de Biología, Universitat de Barcelona, Barcelona, Spain and ${ }^{5}$ Akvaforsk, Institutt for akvakulturforskning, Aas, Norway

Email: Simon MacKenzie* - Simon.MacKenzie@uab.es; Joan C Balasch - JoanCarles.Balasch@uab.es; Beatriz Novoa - virus@iim.csic.es; Laia Ribas - Laia.Ribas@uab.es; Nerea Roher - nroher@ub.edu; Aleksei Krasnov - aleksei.krasnov@akvaforsk.no; Antonio Figueras - antoniofigueras@iim.csic.es

* Corresponding author †Equal contributors

Published: 26 March 2008

BMC Genomics 2008, 9:141 doi:10.1|86/|47|-2|64-9-|4|
Received: I November 2007

Accepted: 26 March 2008

This article is available from: http://www.biomedcentral.com/I47I-2I64/9//4I

(c) 2008 MacKenzie et al; licensee BioMed Central Ltd.

This is an Open Access article distributed under the terms of the Creative Commons Attribution License (http://creativecommons.org/licenses/by/2.0), which permits unrestricted use, distribution, and reproduction in any medium, provided the original work is properly cited.

\begin{abstract}
Background: The response of the trout, $O$. mykiss, head kidney to bacterial lipopolysaccharide (LPS) or active and attenuated infectious hematopoietic necrosis virus (IHNV and attINHV respectively) intraperitoneal challenge, 24 and 72 hours post-injection, was investigated using a salmonid-specific cDNA microarray.

Results: The head kidney response to i.p. LPS-induced inflammation in the first instance displays an initial stress reaction involving suppression of major cellular processes, including immune function, followed by a proliferative hematopoietic-type/biogenesis response 3 days after administration. The viral response at the early stage of infection highlights a suppression of hematopoietic and protein biosynthetic function and a stimulation of immune response. In fish infected with IHNV a loss of cellular function including signal transduction, cell cycle and transcriptional activity 72 hours after infection reflects the tissue-specific pathology of IHNV infection. attlHNV treatment on the other hand shows a similar pattern to native IHNV infection at $\mathbf{2 4}$ hours however at $\mathbf{7 2}$ hours a divergence from the viral response is seen and replace with a recovery response more similar to that observed for LPS is observed.
\end{abstract}

Conclusion: In conclusion we have been able to identify and characterise by transcriptomic analysis two different types of responses to two distinct immune agents, a virus, IHNV and a bacterial cell wall component, LPS and a 'mixed' response to an attenuated IHNV. This type of analysis will lead to a greater understanding of the physiological response and the development of effective immune responses in salmonid fish to different pathogenic and pro-inflammatory agents. 


\section{Background}

The orchestration of a successful immune response to infection requires an integrated tissue response coordinated by specific cytokine and chemokine release. Pathogen-specific immune responses are coordinated and dependent upon the activation of specific pathogen recognition receptors (PRRs), molecular moieties present upon sub-sets of leukocytes such as macrophages or dendritic cells. PRRs respond to pathogens or their PAMPs (Pathogen Associated Molecular Patterns) by the initiation of distinct transcriptomic programmes which will dictate the cellular/tissue response [1-3]. In mammals different transcriptional programmes have been identified by microarray analysis for specific PAMPs (viral, bacteria and yeast) by both macrophages and dendritic cells which initiate the immune response by secreting molecules such as proinflammatory cytokines $[4,5]$.

The availability of salmonid-specific gene chips [6-8] has provided the means to begin to characterise the salmonid immune response at a global gene level both in vitro and in vivo. This technology will provide a deeper understanding of overall cellular and tissue processes during immune activation. A number of recent reports concerning PAMP recognition [9], activated macrophage transcriptomics [8] and immunomics [10-16] and genome-wide surveys [17] show that fish and fish macrophages clearly respond differentially to different pathogens. This therefore should lead to different physiological/immunological responses in vivo upon which the survival of the organism is based.

The head kidney or anterior kidney located posterior to the cranium, is the central hematopoietic organ in salmonids and other fish species. In addition, it contains adrenalin-producing chromaffin cells and also plays a major endocrine role in secretion of cortisol, the major glucocorticoid and mineralocorticoid in fish [18-21]. The head kidney can thus integrate the neuro-immuno-endocrine milieu in normal and pathological states. However, few global gene regulation studies concerning the molecular regulation of head kidney function during infection or PAMP stimulation in salmonids [15] have been reported although many studies have used this tissue as a primary source of macrophage-like cells for studies on the activation of the immune system $[22,23]$.

The Novirhabdovirus infectious hematopoietic necrosis virus (IHNV) is probably one of the most important fish viral pathogens, responsible for great mortalities in farmed salmonids $[24,25]$. As for all the Rhabdoviridae, the genome of IHNV consists of a single-stranded negativesense RNA which has been entirely sequenced $[26,27]$. Their genome codes for five structural proteins: a nucleoprotein $(\mathrm{N})$, a polymerase-associated protein $(\mathrm{P})$, a matrix protein $(\mathrm{M})$, an RNA-dependent RNA polymerase $(\mathrm{L})$ and a surface glycoprotein $(\mathrm{G})$ responsible for immunogenicity [28-30]. An additional gene, only present in some fish rhabdoviruses, located between the $G$ and $L$ genes, encodes a non-structural protein $\mathrm{NV}$, whose putative role in virus replication remains to be fully evaluated [31] but appears to be linked to viral growth and pathogenicity [30]. The strong early immune response elicited by IHNV and other related RNA viruses has favored the development of several vaccines using a reverse genetics approach $[32,33]$; however, recently a DNA vaccine against IHN has been registered in Canada (Novartis Animal Health Canada, Inc).

LPS, the major constituent of the external layer of the outer layer of Gram-negative bacteria, is a widely used PAMP-preparation which induces potent immune responses in which the lipid A portion of the molecule is primarily responsible for the endotoxic properties observed in experimental animals [34,35]. Fish present a remarkable tolerance to LPS challenge in comparison to mammals which has been postulated to be due to differences in receptor-mediated recognition of LPS [36]. In vivo challenge to high concentrations of LPS in fish does not result in endotoxin-mediated mortality [23].

We have carried out in vivo challenges using either live or attenuated IHNV (infectious hematopoietic necrosis virus) or bacterial lipopolysaccharide (E. coli LPS) in trout (Oncorhynchus mykiss). Total RNAs from head kidney tissue were sampled, 1 and 3 days post intra-peritoneal injection (i.p.), and analysed by gene chip analysis. We have identified a generalised immune/stress/hematopoietic gene response to all treatments and a large set of viralspecific genes responding to IHNV infection. Gene ontology analysis presents two distinct physiological responses to either LPS or IHNV in which IHNV pathogenesis can be clearly identified. The response to LPS indicates a general inflammatory response followed by a significant hematopoietic response. Here we present a comparison of the differential gene expression patterns induced in vivo by a generic PAMP, E. coli LPS, and a viral pathogen, IHNV, and an attenuated form of the viral pathogen, attIHNV in the head kidney of the rainbow trout.

\section{Results and Discussion \\ Fish survival and pathogenesis}

The epizootiology of IHN in young fish has been thoroughly described [27,37-42] and includes widespread hemorrhages in kidney, liver and musculature leading to anemia, and extensive necrosis of major hematopioetic tissues (head kidney and spleen). No mortalities, external signs or histological lesions were observed in fish injected with IHNV or attIHNV at sampling time points. The remaining or non-sampled fish displayed the referred pathological features of IHN, arriving to a $100 \%$ mortality 
7-9 days and 15-17 days after challenge with virulent or attenuated IHNV, respectively. In fish challenged with LPS no mortalities were recorded in experimental groups. This is a typical response in which fish do not show an appreciable 'septic shock' type response. A molecular mechanism has been proposed addressing LPS-tolerance in fish which may be due to differential signalling from Toll-like receptors in which the classical TLR4 paradigm differs from that observed in mammals. In fact, rainbow trout macrophages have been shown to be about 1000 times less sensitive to LPS than mammalian macrophages [9].

\section{Overview of viral and LPS-induced differential gene expression in the head kidney}

In order to examine the transcriptional profile of head kidneys (HK) dissected from trout treated with either intra-peritoneal LPS or infection with IHNV or attIHNV we used a salmonid-specific cDNA microarray platform previously validated for studies involving stress, toxicity and immune response in trout $[6-8,43]$.

Total numbers of genes significantly expressed in each of the treatments is shown in fig. 1 and a list of 20 selected genes, ranked by the expression levels was included in tables $1,2,3$. Applying a selection criteria based in a classical cut-off value of $>2$ fold change over the differentially expressed genes $(p<0.01)$ emphasizes the stronger global induction of gene expression following the inoculation of both active and attenuated forms of IHNV (fig. 1b). Within differentially expressed gene groups $(>1$ fold change, $p<0.01$; fig. 1a), bacterial LPS induces a higher response in comparison to viral groups. Although the number of ranked selected genes ( $p$-value $<0.01$ ) is considerably lower than in viral treatments, about $56.5 \%$ (n $=58)$ and $60 \%(n=45)$ of regulated genes at 24 and 72 hours respectively achieve more than 2 fold change in its expression levels, in contrast with attenuated $(15 \% ; \mathrm{n}=$ 413 at $24 \mathrm{~h}$ and $25 \% ; \mathrm{n}=591$ at $72 \mathrm{~h})$ or active $(26 \%, \mathrm{n}=$ 570 at $24 \mathrm{~h}$ and $35.5 \% ; \mathrm{n}=428$ at $72 \mathrm{~h}$ ) viral inoculation of IHNV.

However, using the aforementioned selection criteria $(>2$ fold change; $\mathrm{p}<0.01)$ the magnitude of the transcriptomic response, measured as the number of differentially expressed genes, shows a clear difference between active viral treatment and LPS, the former eliciting an extensive immune, apoptotic and transcriptional response (see the analysis of functional classes below; figs. 2, 3, 4, 5, 6, 7). As shown by the gene representation of the two viral treatments mirroring strength of induction at 1-1.5 fold change levels, transcriptomic responses also include an extensive repertoire of genes expressed below 1.5 fold with $\mathrm{p}<0.01$ that clearly outnumber the 2 -fold expressed genes (Fig. 1a) and can be ascribed to low-level transcriptional, metabolic and homeostasis maintenance pro-
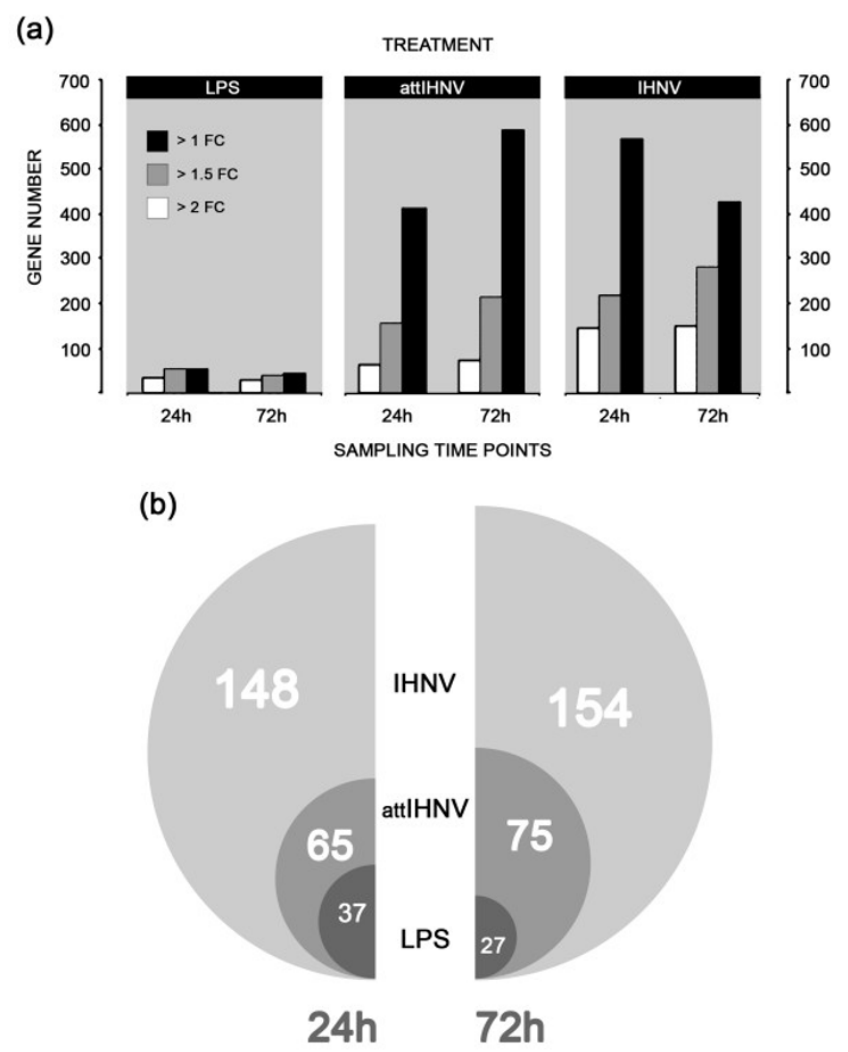

\section{Figure I}

Gene response to lipolysaccharide and viral (active and attenuated IHNV) in the head kidney of trout $(0$. mykiss). (a) Total gene number ( $>$ I fold change; $p<0.0 I$ ) expressed on the microarray in each treatment and in each time point (b) Differentially expressed genes ( $P<0.0$ I; FDR $<0.05$ ) with a 2-fold increase in expression levels are shown for each treatment and time point.

grams (see tables 4, 5 and figs. 2, 3, 4, 5, 6, 7). Whilst it may be expected that an attenuated form of the virus does not induce a similar magnitude of response, the speciesspecific onset of the immune response elicited by the highly antigenic viral glycoprotein $(G)$ of attIHNV may undoubtedly contribute to the observed gene expression pattern, as described in several DNA vaccination assays for fish pathogenic rhabdoviruses $[14,16,33]$.

Not surprisingly, both viral treatments display a $10 \%$ increase in the number of genes regulated $>2$ fold at 72 hours post-treatment. Previous studies on the pathogenicity of IHNV in salmonids typically describe a $24 \mathrm{~h}$ delay in detectable viral titres and internal measures of immunological disturbance, followed by a rapid increase in the differential expression of viral-related and acute phase response genes in major haematopoietic organs and liver, respectively $[42,44]$. In addition, a tissue-specific effect determines the dynamics of the transient cellular popula- 
Table I: List of top 20 up and down regulated genes in the head kidney of trout, 24 and 72 hours after i.p. injection of LPS. Genes were selected for significant differential expression at $p<0.01$ (FDR $<0.05)$. Values are expressed as FC, fold change.

\begin{tabular}{|c|c|c|c|c|c|c|c|}
\hline \multicolumn{2}{|l|}{24 hours UP } & \multicolumn{4}{|c|}{72 hours UP } & \multirow[b]{2}{*}{ FC } & \multirow[b]{2}{*}{$p$} \\
\hline Clone ID & Clone Name & FC & $p$ & Clone ID & Clone Name & & \\
\hline est03dII & Unknown-42 & 8.42 & 0.000 & est03dII & Unknown-42 & 3.81 & 0.000 \\
\hline est04b0l & Similar to rRNA (Vang|2) & 4.54 & 0.004 & est03e02 & Hypothetical-fish 15 & 3.39 & 0.001 \\
\hline EXOBI_H05 & Transposase- 6 & 3.16 & 0.000 & est04e04 & MHC class Ib antigen & 3.17 & 0.006 \\
\hline EXOB2_D06 & NADH dehydrogenase subunit $5-I$ & 2.76 & 0.000 & EXOB2_H06 & High affinity immunoglobulin epsilon receptor alpha & 2.73 & 0.003 \\
\hline est02g07 & Ig mu heavy chain disease protein & 2.73 & 0.001 & CA387837 & Nucleolar protein NAP57 & 2.27 & 0.000 \\
\hline est02all & Ig kappa chain $\mathrm{V}-\mathrm{IV}$ region $\mathrm{B}$ I7-2 & 2.71 & 0.002 & EXOB4_CII & High affinity immunoglobulin gamma Fc receptor I precursor & 2.15 & 0.008 \\
\hline ESTI-3A_G09 & Unknown-75 & 2.32 & 0.001 & ENH2_FO9 & Beta-2-microglobulin-I & 1.99 & 0.004 \\
\hline CA383564 & Coatomer epsilon subunit I & 2.25 & 0.001 & EXOB2_A09 & $60 S$ ribosomal protein $L 5-2$ & 1.80 & 0.005 \\
\hline est04e04 & MHC class Ib antigen & 2.24 & 0.007 & HST000I_C05 & Cell division control protein 42 homolog & 1.72 & 0.009 \\
\hline ESTI-3A_FI2 & Transposase- 59 & 2.12 & 0.001 & EXOB3_F09 & MHC class I heavy chain-I & 1.71 & 0.001 \\
\hline HK0002_D09 & Prothymosin alpha & 2.03 & 0.003 & est0 $\lg 04$ & 5-aminolevulinate synthase & 1.58 & 0.010 \\
\hline est02e09 & Ig heavy chain V-III region HIL & 2.00 & 0.005 & & & & \\
\hline EXOB4_DI2 & Hpa repeat-I & 1.99 & 0.001 & & & & \\
\hline HK0003_E06 & DnaJ homolog subfamily $\mathrm{C}$ member 9 & 1.96 & 0.005 & & & & \\
\hline HK0003_E08 & Unknown-194 & 1.90 & 0.007 & & & & \\
\hline est04g12 & Envelope protein & 1.90 & 0.004 & & & & \\
\hline HK0002_H08 & TATA-binding protein associated factor $2 \mathrm{~N}$ & 1.79 & 0.003 & & & & \\
\hline CA387665 & Cytochrome P450 2/2 & 1.79 & 0.000 & & & & \\
\hline est0Ih0l & Unknown-19 & 1.76 & 0.009 & & & & \\
\hline est03bl I & Acidic leucine-rich nuclear phosphoprotein $32 \mathrm{~A}-\mathrm{I}$ & 1.68 & 0.008 & & & & \\
\hline
\end{tabular}

\section{4 hours DOWN}

72 hours DOWN

EXOB2_D07

HST000I_C04

ESTI-3A_D08

EXOBI_H06

ESTI-3A_H06

est03f08

EXOB2_HOI

est02f08

ESTI-3A_A09

CA37I363

HST000I_D08

est04e05

est0Ic04

EXOB2_D05

est0lelo

CA348284

est03c04

EXOB2_GI2

ESTI-3A_B03

EXOB3_HOI
Hemoglobi

Glyceraldehyde-3-phosphate dehydrogenase- 6

CC chemokine SCYAII0-2

ranscription factor jun-B-I

Transaldolase

Unknown-100

Serine protease-like protein-I

Serine protease-like protein-2

Glucose-6-phosphate isomerase- 1

Beta-globin

Glutathione peroxidase-gastrointestina

Unknown-II

Matrix metalloproteinase 9-2

Tolloid-like protein (nephrosin)-I

CCAAT/enhancer binding protein beta

Matrix metalloproteinase- 9

Tolloid-like protein (nephrosin)-2

Hypothetical-fish 44

Matrix metalloproteinase-13

$\begin{array}{lll}-2.28 & 0.002 & \text { est04cI0 } \\ -2.42 & 0.004 & \text { CA367764 } \\ -2.49 & 0.009 & \text { est03c04 } \\ -2.55 & 0.005 & \text { HKT000I_E07 } \\ -2.89 & 0.003 & \text { est0If03 } \\ -2.91 & 0.002 & \text { est0le02 } \\ -2.91 & 0.002 & \text { EXOB3_G05 } \\ -2.97 & 0.000 & \text { ESTI-3A_D08 } \\ -3.96 & 0.003 & \text { ESTI-3A_B03 } \\ -4.35 & 0.000 & \text { CA348284 } \\ -4.46 & 0.000 & \text { CA374I93 } \\ -4.54 & 0.000 & \text { utu04f08 } \\ -6.17 & 0.001 & \text { KVkm2_F0I } \\ -6.63 & 0.000 & \text { est0If0I } \\ -6.69 & 0.001 & \text { est02f08 } \\ -7.36 & 0.006 & \text { ESTI-3A_A09 } \\ -7.44 & 0.000 & \text { EXOB3_H0I } \\ -9.26 & 0.000 & \text { EXOB2_H0I } \\ -14.01 & 0.000 & \text { est0Iel0 } \\ -17.18 & 0.000 & \text { EXOB2_GI2 }\end{array}$

Unknown-56

Calmodulin-I

Matrix metalloproteinase-9

Actin, alpha skeletal I

Deltex protein I

Thymosin beta-4-I

Actin, cytoplasmic 2

Glyceraldehyde-3-phosphate dehydrogenase-6

$-2.04 \quad 0.000$

Hypothetical-fish 44

CCAAT/enhancer binding protein beta

Chemokine receptor CXCR4

Actin, alpha skeletal 5

Unknown-224

DNA-binding protein inhibitor ID-I

Serine protease-like protein-I

Serine protease-like protein-2

Matrix metalloproteinase-13

Unknown-100

Tolloid-like protein (nephrosin)-

Tolloid-like protein (nephrosin)-2 $\begin{array}{ll}-2.13 & 0.001\end{array}$

$\begin{array}{ll}-2.21 \quad 0.000 \\ -2.28 & 0.002\end{array}$

$\begin{array}{ll}-2.28 & 0.002 \\ -2.37 & 0.001\end{array}$

$\begin{array}{ll}-2.37 & 0.001\end{array}$

$\begin{array}{ll}-2.73 & 0.002\end{array}$

$\begin{array}{ll}-2.78 \quad 0.000 \\ -3.14 & 0.000\end{array}$

$-3.14 \quad 0.000$

$-3.16 \quad 0.007$

$\begin{array}{ll}-3.22 & 0.003\end{array}$

$\begin{array}{ll}-3.71 & 0.000 \\ -3.81 & 0.001\end{array}$

$\begin{array}{ll}-3.81 & 0.001\end{array}$

$\begin{array}{ll}-4.21 \quad 0.000 \\ -4.64 & 0.000\end{array}$

$\begin{array}{ll}-4.64 & 0.000\end{array}$

$\begin{array}{ll}-4.64 & 0.001\end{array}$

$\begin{array}{ll}-5.52 & 0.000\end{array}$

$\begin{array}{ll}-5.88 & 0.007\end{array}$

$\begin{array}{ll}-12.08 & 0.000\end{array}$

$\begin{array}{ll}-12.97 \quad 0.000 \\ -13.47 & 0.000\end{array}$

$-13.47 \quad 0.000$ 
Table 2: List of top 20 up and down regulated genes in the head kidney of trout, 24 and 72 hours after i.p. injection of attlHNV. Genes were selected for significant differential $\mp$ expression at $p<0.01$ (FDR $<0.05$ ). Values are expressed as FC, fold change.

\begin{tabular}{|c|c|c|c|c|c|c|c|}
\hline \multirow{2}{*}{$\begin{array}{l}24 \text { hours UP } \\
\text { Clone ID }\end{array}$} & \multicolumn{7}{|c|}{72 hours UP } \\
\hline & Clone Name & FC & $p$ & Clone ID & Clone Name & $\mathbf{F C}$ & $p$ \\
\hline EXOB2_BIO & Hemoglobin beta chain & 19.46 & 0.000 & est03e08 & Hypothetical-fish 36 & 3.06 & 0.000 \\
\hline HSTO00I_C04 & Hemoglobin alpha chain & 11.19 & 0.000 & CA343473 & C3a anaphylatoxin chemotactic receptor & 2.98 & 0.000 \\
\hline KVkm2_A0I & Unknown-219 & 10.93 & 0.000 & EXOB2_GII & Stanniocalcin-I & 2.93 & 0.000 \\
\hline HST000I_D04 & Alpha-globin I-2 & 10.93 & 0.000 & EXOBI_B02 & Hypothetical-fish 34 & 2.84 & 0.000 \\
\hline EXOB4_A03 & Carbonic anhydrase & 10.57 & 0.000 & KVkm2_H07 & Unknown-226 & 2.77 & 0.000 \\
\hline CA366564 & Huntingtin & 8.52 & 0.000 & EXOB3_A0I & Unknown- 103 & 2.73 & 0.000 \\
\hline EXOB2_BI2 & RING finger protein 103 & 8.34 & 0.000 & CA363723 & Cyclin C & 2.64 & 0.000 \\
\hline HST000I_C07 & Unknown-213 & 7.60 & 0.000 & EXOB4_HOI & Unknown-I 32 & 2.63 & 0.000 \\
\hline $\mathrm{ENH} 2$ E07 & Unknown-3 & 7.04 & 0.000 & est04c02 & Unknown-53 & 2.61 & 0.000 \\
\hline EXOB4__G09 & Histone $\mathrm{HI} 4$ & 6.94 & 0.000 & HK0002_G04 & Fructose-bisphosphate aldolase A & 2.45 & 0.000 \\
\hline EXOB4_H06 & Alpha-globin I-3 & 6.63 & 0.000 & ESTI-3A_H03 & Unknown-76 & 2.42 & 0.000 \\
\hline utu0le09 & Embryonic alpha-type globin2+collagen alpha $2(I)$ & 4.94 & 0.000 & CA358107 & Ectonucleoside triphosphate diphosphohydrolase I & 2.42 & 0.000 \\
\hline HK0002_G02 & Creatine kinase, sarcomeric mitochondrial precursor & 4.49 & 0.000 & CA37836I & Ubiquitin ligase SIAHI & 2.40 & 0.000 \\
\hline HK000I_C08 & Galectin-9 (VHSV-induced protein)-3 & 4.14 & 0.000 & HK000I_HI2 & Unknown-162 & 2.35 & 0.000 \\
\hline CA36II0I & Regulator of G-protein signaling I-2 & 4.03 & 0.000 & CA342204 & TNF receptor associated factor 3 & 2.33 & 0.000 \\
\hline est02all & Ig kappa chain V-IV region $\mathrm{BI}$ 7-2 & 3.19 & 0.000 & ESTI-3A_H05 & Adenosine deaminase 3 & 2.31 & 0.000 \\
\hline CA343473 & C3a anaphylatoxin chemotactic receptor & 3.00 & 0.000 & est04flo & Hypothetical-fish I & 2.30 & 0.000 \\
\hline est04b0I & Similar to rRNA (Vangl2) & 2.69 & 0.000 & KVkm2_HII & Unknown-228 & 2.30 & 0.000 \\
\hline HST000I_D02 & ATP-binding cassette, sub-family $F$, member 2 & 2.58 & 0.000 & HKT000̄I_AII & Hypothetical-fish II & 2.28 & 0.000 \\
\hline $\mathrm{CA} 384134$ & GI/S-specific cyclin D2 & 2.56 & 0.000 & CA355893 & Dnaj homolog subfami.B member 2 & 2.26 & 0.000 \\
\hline 24 hours DOWN & & & & 72 hours DOV & & & \\
\hline est0lelo & Tolloid-like protein (nephrosin)-I & -2.60 & 0.000 & EXOB2_G02 & Profilin-I & -2.13 & 0.000 \\
\hline est03c04 & Matrix metalloproteinase- 9 & -2.70 & 0.000 & EXOB2_FI2 & $60 S$ ribosomal protein $\mathrm{L7a}-\mathrm{I}$ & -2.13 & 0.000 \\
\hline HST000I_C03 & Plasminogen precursor-2 & -2.72 & 0.000 & est02gII & Cytochrome c oxidase subunit I-I & -2.14 & 0.000 \\
\hline KVkm2_HIO & Unknown-227 & -2.76 & 0.000 & HK000I_H03 & 60 S ribosomal protein $\mathrm{L} 26$ & -2.14 & 0.000 \\
\hline CA34828 & CCAAT/enhancer binding protein beta & -3.05 & 0.000 & HK0003_AI2 & Heterogeneous nuclear ribonucleoprotein AI-I & -2.16 & 0.000 \\
\hline EXOB2_D05 & Matrix metalloproteinase $9-2$ & -3.07 & 0.000 & EXOBI_HI2 & $\mathrm{NADH}$ dehydrogenase subunit 4 & -2.23 & 0.000 \\
\hline est02f08 & Serine protease-like protein-I & -3.21 & 0.000 & HK0002_D07 & Unknown-172 & -2.24 & 0.000 \\
\hline ESTI-3A_A09 & Serine protease-like protein-2 & -3.25 & 0.000 & EXOB3_G03 & $60 S$ acidic ribosomal protein $P 2$ & -2.31 & 0.000 \\
\hline HK0003_CII & Tropomyosin alpha 3 chain-I & -3.34 & 0.000 & EXOB2_G09 & Cytochrome $\mathrm{c}$ oxidase subunit $\mathrm{I}-2$ & -2.34 & 0.000 \\
\hline utu03e06 & Parvalbumin alpha-3 & -3.50 & 0.000 & HST000I_D04 & Alpha-globin I-2 & -2.37 & 0.000 \\
\hline CA370329 & Lysozyme C precursor & -3.90 & 0.000 & $\mathrm{ENH} 2 \_\mathrm{H} 06$ & Unknown-5 & -2.46 & 0.000 \\
\hline HK0003_C08 & Parvalbumin alpha-2 & -3.99 & 0.000 & est04c05 & Ferritin heavy chain-I & -2.54 & 0.000 \\
\hline utu04hl & Myosin light chain 2-2 & -4.13 & 0.000 & P_46 & ATPase 6 & -2.56 & 0.000 \\
\hline utu02c02 & Myosin heavy chain, skeletal, adult I-I & -4.30 & 0.000 & utu02b07 & Cytochrome c oxidase subunit II & -2.64 & 0.000 \\
\hline Hete0002_A07 & Metallothionein-IL & -4.49 & 0.000 & KVkm2_HIO & Unknown-227 & -2.67 & 0.000 \\
\hline HK0003_E07 & Myosin light chain 2-I & -4.49 & 0.000 & ESTI-3A_H07 & Cytochrome b-I & -2.86 & 0.000 \\
\hline HK0002_D07 & Unknown-172 & -5.04 & 0.000 & est02h09- & Nonhistone chromosomal protein HMG-I7 & -3.07 & 0.000 \\
\hline EXOBI_A03 & Metallothionein A & -5.05 & 0.000 & CA370329 & Lysozyme C precursor & -3.08 & 0.000 \\
\hline est0 Ic04 & Unknown-II & -6.17 & 0.000 & EXOBI_C02 & Unknown-83 & -3.44 & 0.000 \\
\hline HK0002_F05 & Myosin heavy chain, skeletal, fetal & -7.31 & 0.000 & EXOB2_GOI & Leukocyte cell-derived chemotaxin 2 & -3.56 & 0.000 \\
\hline
\end{tabular}


Table 3: List of top 20 up and down regulated genes in the head kidney of trout, 24 and 72 hours after i.p. injection of active IHNV. Genes were selected for significant differential expression at $p<0.01$ (FDR $<0.05)$. Values are expressed as FC, fold change.

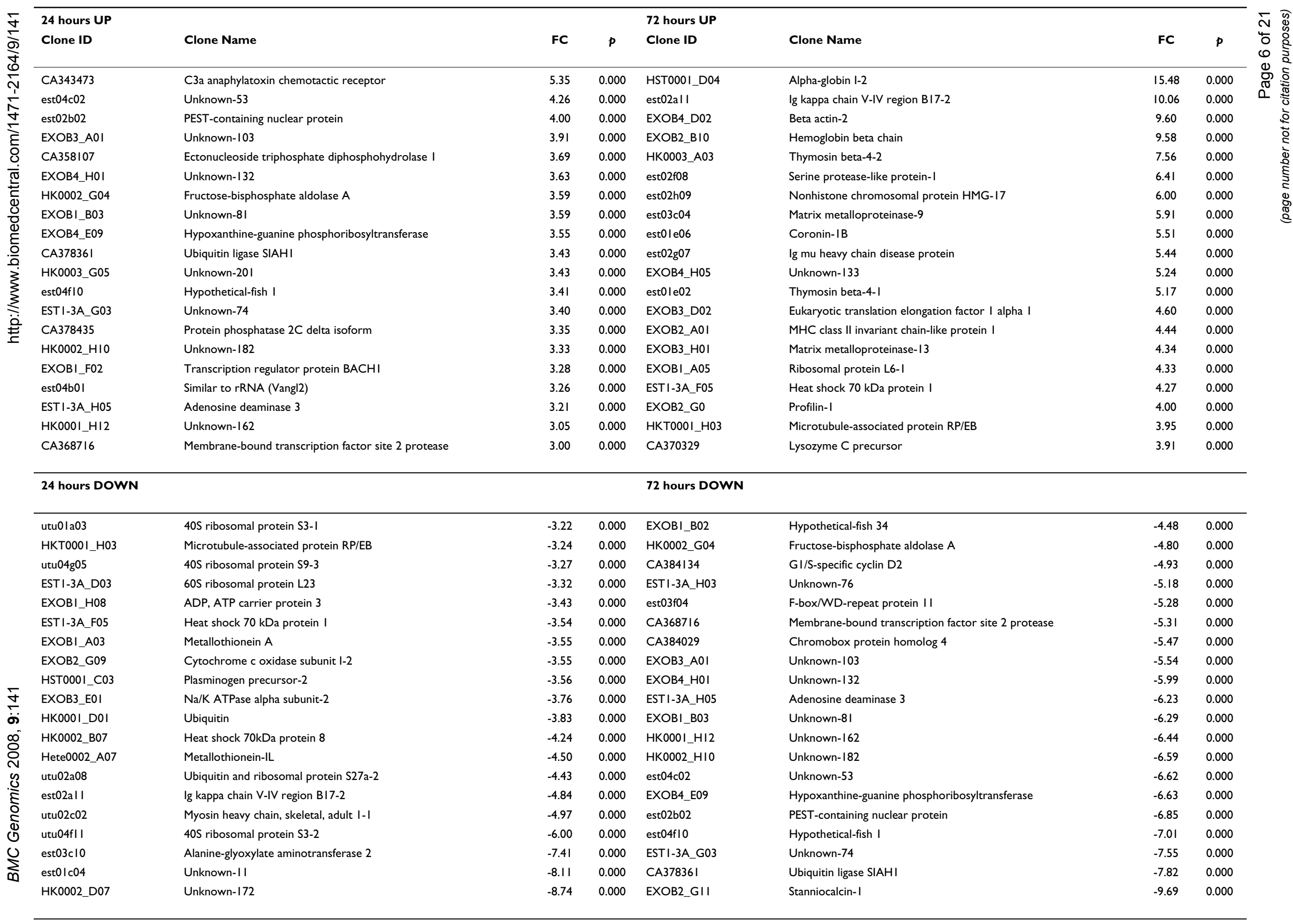



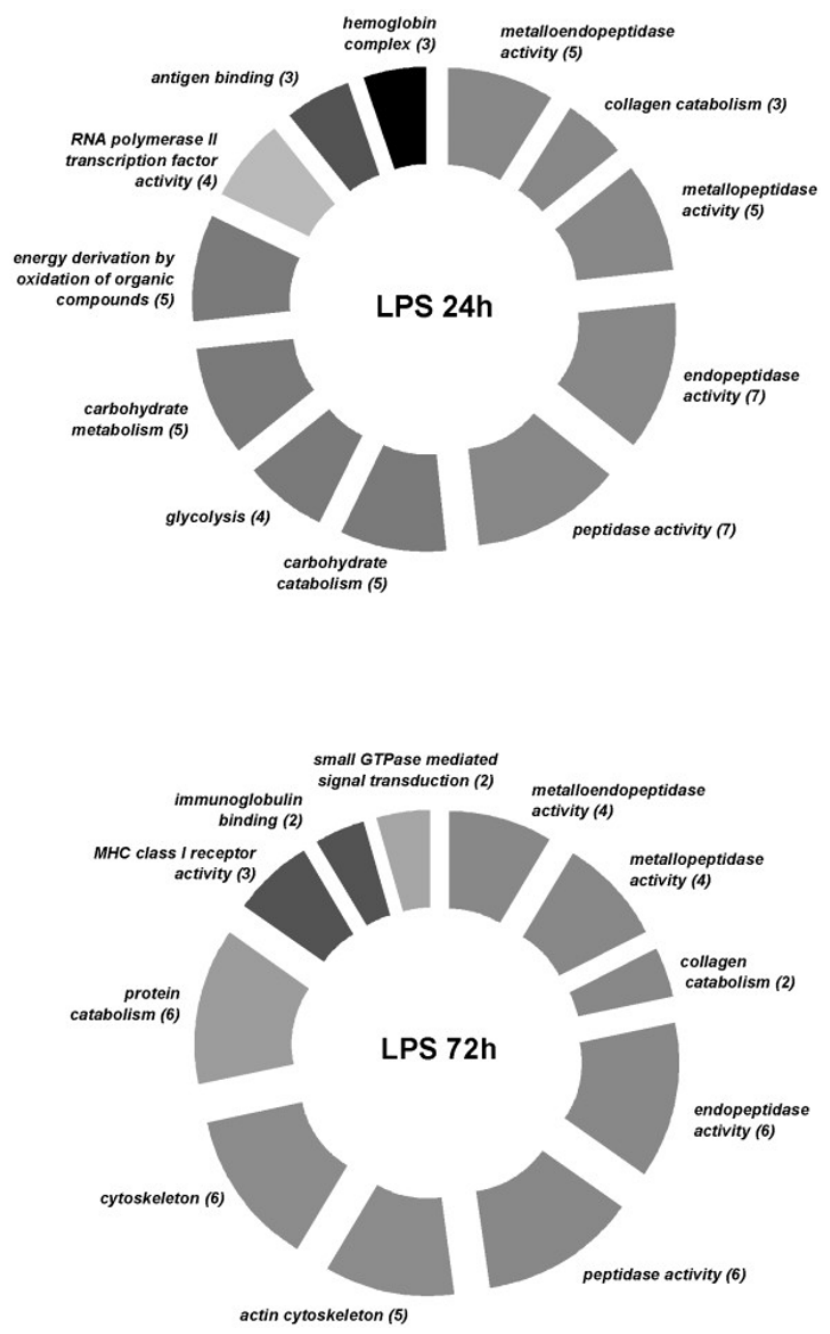

Figure 2

Over represented GO functional classes in LPS array experiments. Functional categories with Yates corrected Chi squared $p<0.05$ were selected. Number of regulated genes for each category is shown in parenthesis.

tions during inflammation and, subsequently, the tissuedependent gene expression profile. It has been suggested [45] that the transient double stranded RNA intermediates produced by the accelerated replication of IHNV 24 hours post infection seem to regulate the expression of trout Toll-like Receptor 3 (rtTLR3) in a unpredictable manner, strongly dependent on viral growth and host lymphocyte recirculation cycles. Interestingly, the pattern of rtTLR3 expression in response to Yersinia ruckeri, a gram-negative bacterial trout pathogen shows a remarkably lower magnitude in terms of fold change compared with the viral challenge [45], mimicking the magnitude of the response between LPS and IHNV/attIHNV treatments described above (fig 1b). Although both treatments display increases in the number of regulated genes the pat-
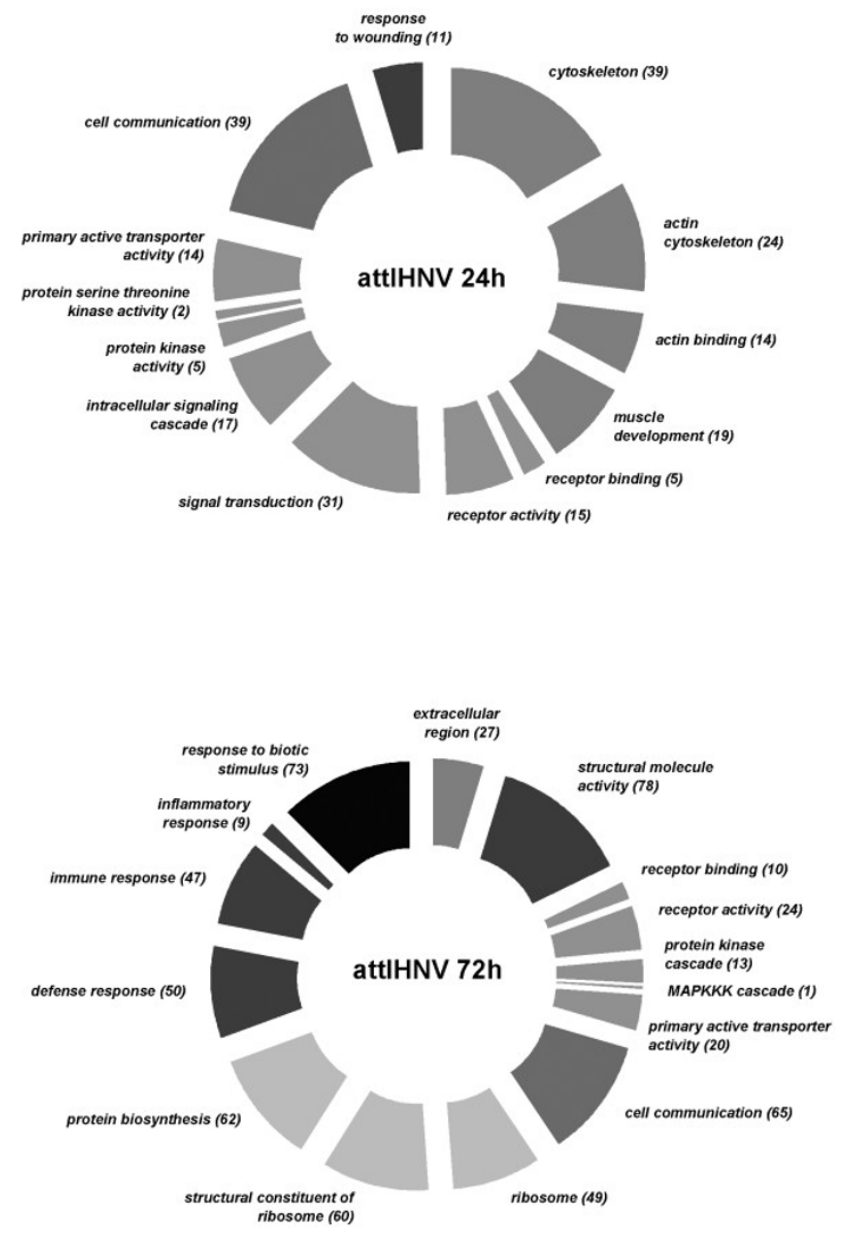

Figure 3

Over represented GO functional classes in attIHNV array experiments. Functional categories with Yates corrected Chi squared $p<0.05$ were selected. Number of regulated genes for each category is shown in parenthesis

terns of gene expression are also significantly different. The number of genes regulated show that LPS induces in the majority a down-regulation of gene expression at both time points. Similar results were observed in LPS-stimulated macrophages derived from trout, O. mykiss, analysed with the same platform [8]. Highest fold changes in individual genes were observed in down-regulated genes in the LPS groups (table 1). On the other hand, viral treatments induce a higher induction of transcriptomic and cell cycle/apoptotic activity where induction and suppression processes display a similar weighting (tables 2 and $3)$.

The viral treatments show the highest differential gene expression counts obtained when compared across all available experiments in our gene (KuopioChip) database. This observation, together with the extensive tran- 

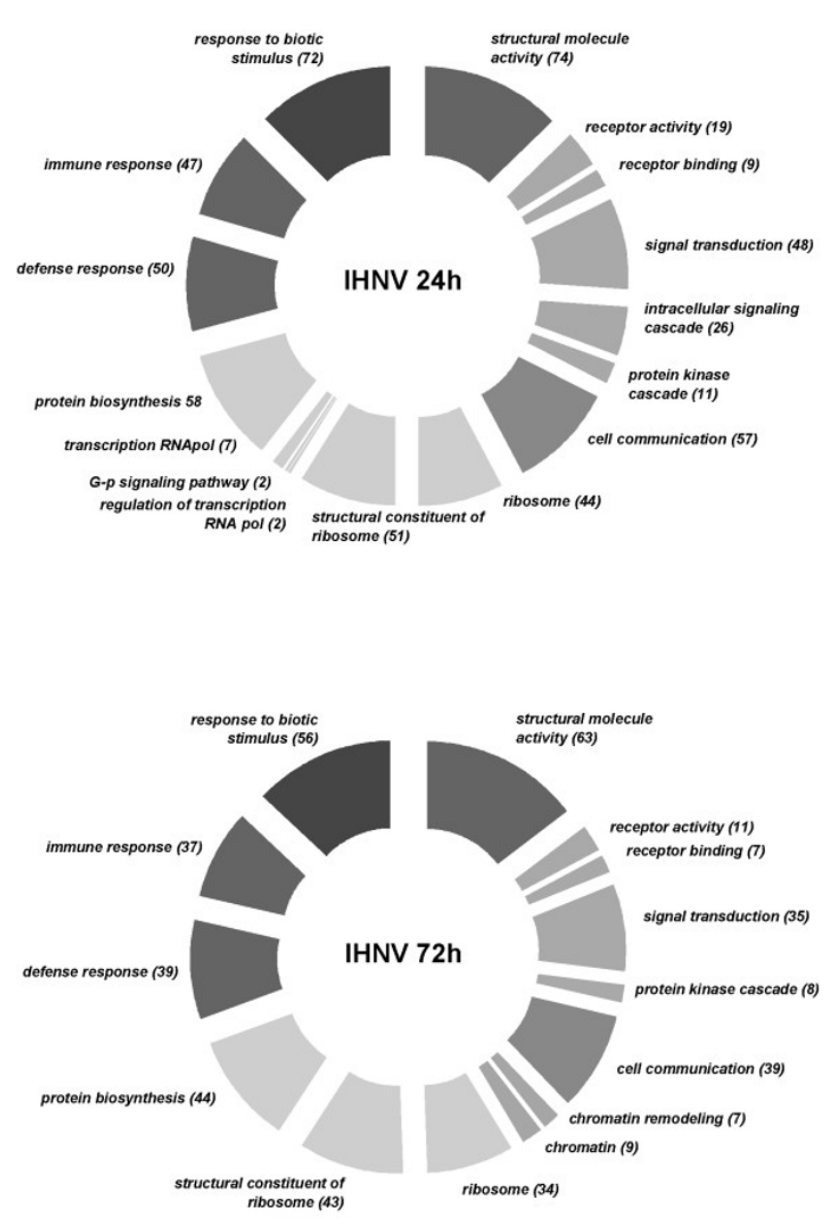

Figure 4

Over represented GO functional classes in IHNV array experiments. Functional categories with Yates corrected $C$ hi squared $p<0.05$ were selected. Number of regulated genes for each category is shown in parenthesis.

scriptional onset observed in the analysis of functional ontology categories in viral treatments (see below), follows that of Abbas et al. (2006) suggesting that a specific immune response mobilizes more transcriptional remodelling than the majority of physiological responses.

\section{Specific vs. common gene responses}

From the selected differentially expressed genes $(p<0.01)$ in LPS and viral treatments, the differential response in LPS and viral treatments (significant differential expression in at least 5 of the 6 experiments) was evaluated across 155 experiments in our gene database (KuopioChip) in order to ascertain those genes co-expressed (Fischer's exact $\mathrm{P}<0.01$ ) in each or both experimental conditions (minimum requirement was significant differential expression in at least 5 of the 6 experiments). A total of 49 genes were identified from which many genes showed opposite responses representative of directional responses to viral and LPS-induced stimuli (table 4 and $5)$.

Interestingly genes regulated by the attIHNV treatment show a mixture of effects both similar and different to LPS and IHNV suggesting that different mechanisms, non-specific and specific response, of activation are induced by the attenuated virus in the head kidney. Alpha globin for example shows down regulation by LPS whereas attIHNV initially induces expression, 11 fold, followed by suppression, -2.37 fold. On the other hand IHNV causes suppression at 24 hours followed by strong induction, 15 fold. LPS and attIHNV show similar profiles for: Glucose-6phosphate isomerase, annexin 1, the nephrosin proteins, calmodulin-1, CEBP-beta, cysteine-rich protein-1, cytochrome oxidase and cytochrome p-450. The majority of the genes are related to immunity and the inflammatory response. Suppression of HK proteases, nephrosin and MMPs, seems to be one of the most characteristic effects of LPS (Nephrosins FC; 24 hours; -6.69 and -9.26 and 72 hours -12.97 and -13.47) whereas viral treatment causes a similar initial effect followed by induction of expression (FC at 72 hours; attIHNV 1.44 and IHNV 2.98 and 3.7). Serine protease-like proteins 1 and 2 (spl1 and spl2) are also highly suppressed by LPS, attIHNV and IHNV at 24 hours. This suppression continues in the LPS treatment, however in viral samples we observe a significant increase in expression in the 72 hour samples (attIHNV; 1.32 both spl1 and 2, IHNV; 6.4 and 3.75). Several cytoskeleton related genes including ARP2/3, the actin and profilin-1 are down-regulated by both LPS and attIHNV whereas IHNV induces up-regulation of all genes in this group at 72 hours post-infection.

Viral treatments induce a typical adaptive immune response (table 5). The antigen processing/presenting loading pathways include the differential expression of MHC Class I and lymphoid and myeloid cell lineages, as shown by the regulation of B-cell specific coactivator OBF1 , essential for the response of B-cells to antigens and required for the formation of germinal centers, the conservation of BTK B-cell, HCK neutrophil and TNFalpha receptor signaling pathways, the cathepsin mediated antigen processing and the interferon-inducible RNA-specific adenosine deaminase ADAR1 (table 5).

Not surprisingly, NF-kappa-B (NFkB) signal transduction suffered from moderate to severe regulation in the head kidney of infected trout (tables 3 and 4). NFkB is considered a pleiotropic transcription factor expressed in several cell types undergoing amongst others inflammatory assaults. Both active IHNV and attIHNV treated fish showed differential regulation of Inhibitor of kappaB kinase gamma, member of a family of proteins which 


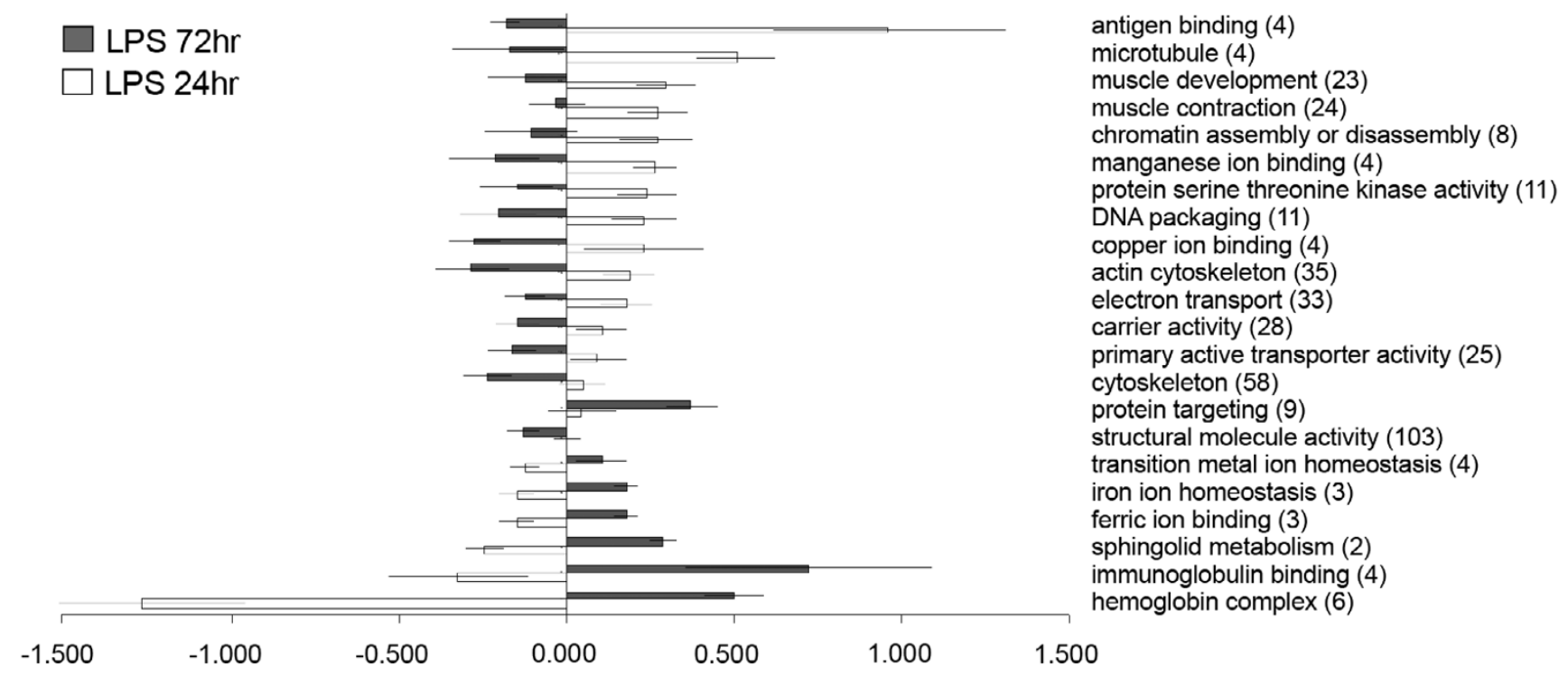

Figure 5

Gene Ontology analysis for LPS treatment. Results show categories with significant difference, (pair comparison independent test, $p<0.05$ ), chosen from categories which had a $p$-value $<0.01$ from individual treatment groups. Data is shown as mean fold change \pm std.error.

inactivate NFkB by trapping it in the cell cytoplasm [46] and are actively expressed in virus infected cells [47].

The anaphylactic arm of the complement activation acts in a double fashion through the component $\mathrm{C} 3 \mathrm{a} /$ C3aReceptor: as a chemotactic mediator involved in endotoxic responses and, simultaneously, as a regulator of homing and mobilizations of hematopoietic stem cells (see below). Both complement related serine proteases (spl) and C3 proteolytic components were differentially expressed in LPS-induced or viral treatments. However, the highest levels of complement expression seem to be strongly dependent of viral invasions in fish head kidney (tables 3 and 5)

\section{Stromal protease activity and extracellular matrix remodelling in trout head kidney}

Although the precise function of nephrosin, an astacin metalloproteinase [48] remains unresolved, it has been shown to be involved in the late stages of granulocyte differentiation and cell migration and/or tissue infiltration processes in challenged carp and zebrafish $[49,50]$. In trout treated with LPS, the two nephrosin proteins genes are severely down regulated (between -6 and -10 fold) at both time points (fig. 1). The rest of metalloproteinases (MMP 9-2,13) also showed a marked decrease of expression in LPS treated trout (less than - 6 fold change) at both time points and at $24 \mathrm{~h}$ in IHNV or attIHNV infected fish ( -1.3 to -3 fold; see table 2 and additional file 1$)$, therefore suggesting a decrease in extracellular matrix remodeling and leukocyte movement.

In mammals, MMP 9 has been implicated in the signal processing and maturation of dendritic cells, IL- 8 mediated activation of neutrophils and undifferentiated hematopoietic stem cells [51,52]. Whilst the existence of functionally differentiated dendritic cells in fish is still controversial $[53,54]$, the mammalian leukocyte response outlined for IL-8 and MMP 9 seems to be conserved in teleosts, although the exact pattern of organ distribution, the intensity of gene regulation and the voluble species-specific expression of IL-8 in fish HK remains obscure $[55,56]$. The chemotatic properties of IL- 8 on leukocytes are amplified by the recruitment of neutrophils mediated by CXC chemokines. Our data show a moderate (-3.71 fold change) down-regulation of trout CXCR4. Mammalian CXCR4 forms with TNFalpha, several HSP proteins and GDF5 an activation cluster involved in monocyte LPS signal transduction [57] and also acts synergistically with the colony-stimulating factor mediated mobilization of hematopoietic stem cells $[57,58]$.

The MMP gene family appears to be induced by LPS in trout macrophages [8], and a widescreen transcriptomic analysis of carp metalloproteinases detected a large amount of MMP9 mRNA mainly in hematopoietic organs, HK and spleen $[59,60]$. Fish metalloproteinases thus probably act in a mammalian fashion, showing and 


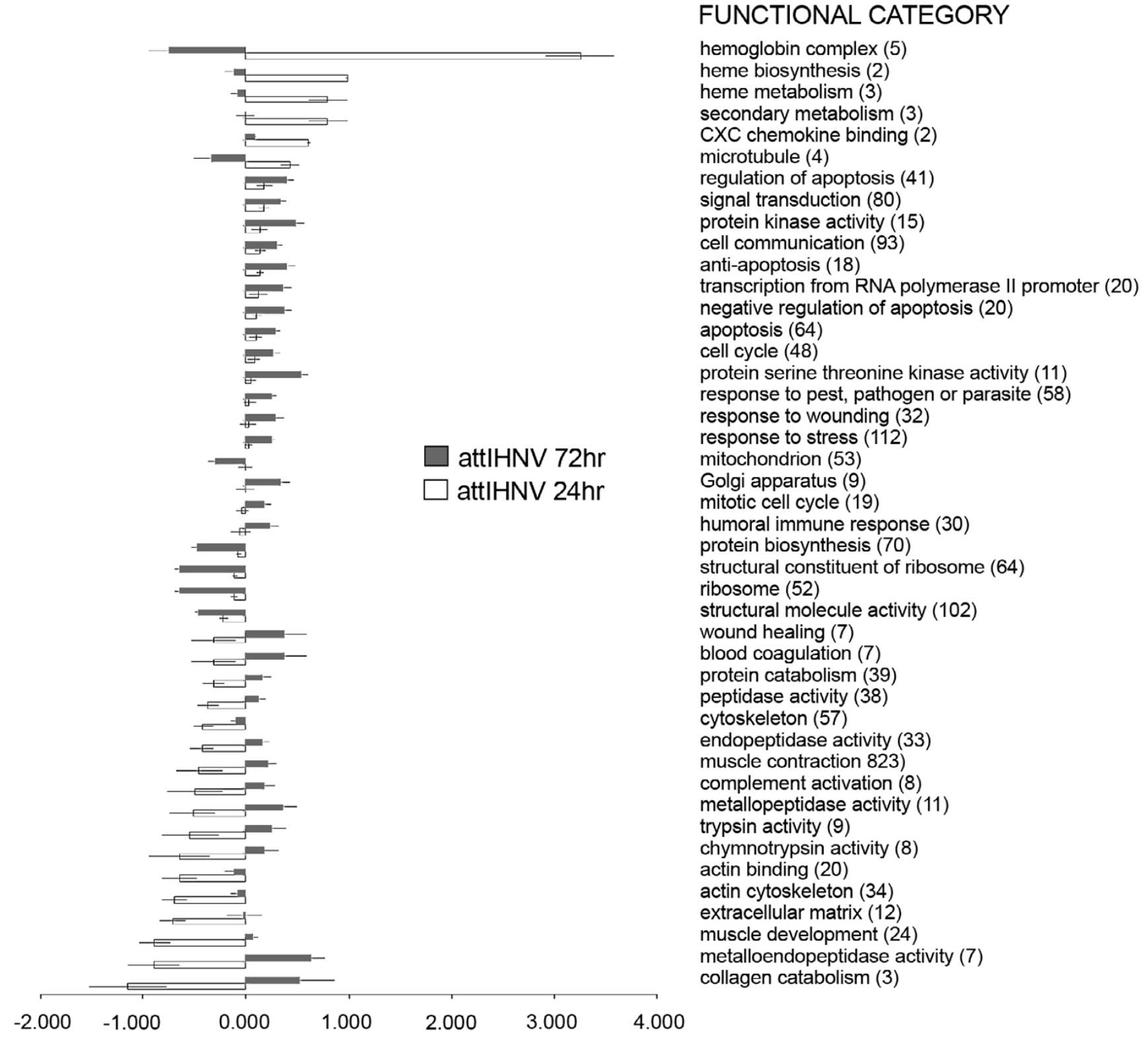

\section{Figure 6}

Gene Ontology analysis for attIHNV treatment. Results show categories with significant difference, (pair comparison independent test, $p<0.05$ ), chosen from categories which had a $p$-value $<0.01$ from individual treatment groups. Data is shown as mean fold change \pm std.error.

up-regulation by the synergistic stimulation of Tumor Necrosis Factor alpha (TNFalpha) and LPS. In agreement with the low level expression of MMPs observed $24 \mathrm{~h}$ post injection, no significant amounts of TNFalpha mRNA were detected in LPS treated trout, in contrast with IHNV infected fish. Both myeloperoxidase, a lysosomal hemoprotein characteristic of mononuclear phagocytes, and TNF were up regulated $24 \mathrm{~h}$ post injection of attenuated IHNV in trout HK (2.3 and 2.6 fold, respectively). In the active viral group, however, TNFalpha was found to be inactive (see below). The moderate up-regulation of TNFalpha 3 days post attIHNV stimulation (table 2) may suggest, according to the well described model of macrophage stimulation by LPS [8], the onset of a proliferative myeloid response in the principal hematopoietic organ.

Intracellular thymosin beta- 4 (TBX4) is considered the main G-actin sequestering peptide in mammals [61]. The 


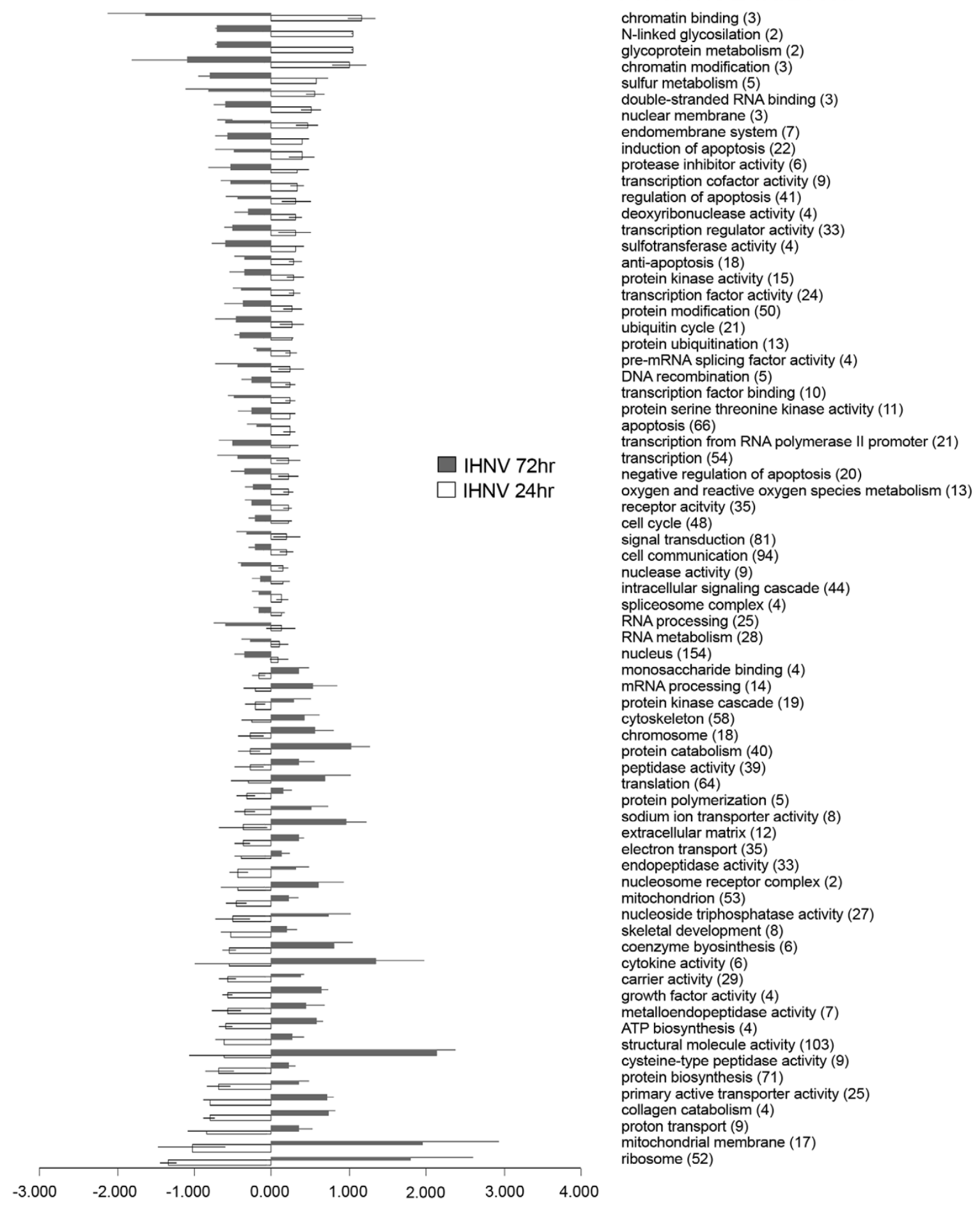

\section{Figure 7}

Gene Ontology analysis for IHNV treatment. Results show categories with significant difference, (pair comparison independent test, $p<0.05$ ), chosen from categories which had a $p$-value $<0.01$ from individual treatment groups. Data is shown as mean fold change \pm std.error. 
Table 4: Genes common to all treatments. Genes selected were expressed in a minimum of 5 of the 6 experiments and compared against all experiments in the database $(n=155)$. Only genes specific to these experiments were chosen (Fischer's exact Test, $p<$ $0.0 \mathrm{I})$. Values are expressed as FC, fold change.

\begin{tabular}{|c|c|c|c|c|c|c|c|}
\hline \multirow[t]{2}{*}{ Clone ID } & \multirow[t]{2}{*}{ Clone Name } & \multicolumn{2}{|c|}{ LPS (FC) } & \multicolumn{2}{|c|}{ AttIHNV (FC) } & \multicolumn{2}{|c|}{ IHNV (FC) } \\
\hline & & $24 \mathrm{hr}$ & $72 \mathrm{hr}$ & $24 \mathrm{hr}$ & $72 \mathrm{hr}$ & $24 \mathrm{hr}$ & $72 \mathrm{hr}$ \\
\hline CA384637 & $60 \mathrm{kDa}$ heat shock protein-I & - & 1.47 & 1.18 & 1.25 & -1.25 & 1.29 \\
\hline est03bll & Acidic leucine-rich nuclear phosphoprotein $32 \mathrm{~A}-\mathrm{I}$ & 1.68 & 1.41 & 1.17 & 1.32 & 1.27 & 1.34 \\
\hline utu0If04 & Actin, alpha skeletal 2 & - & $-|.3|$ & -1.48 & 1.18 & 1.52 & 1.29 \\
\hline utu0 Igl I & Actin, alpha skeletal 3 & 1.67 & -1.64 & -1.47 & -1.25 & 1.34 & 1.42 \\
\hline utu04d04 & Actin, alpha skeletal 4 & 2.00 & -1.30 & -1.18 & - & 1.61 & 1.37 \\
\hline ESTI-3A_H05 & Adenosine deaminase 3 & 1.57 & - & 1.14 & 2.31 & 3.21 & -6.23 \\
\hline HST000I_D04 & Alpha-globin I-2 & -1.30 & - & 10.93 & -2.37 & -3.11 & 15.48 \\
\hline CA36494I & Annexin $\mathrm{Al}-\mathrm{I}$ & -2.08 & -1.78 & -1.36 & -1.46 & -1.26 & 1.68 \\
\hline$F_{-} 122$ & ARP2/3 complex $21 \mathrm{kDa}$ subunit & - & -.192 & $-1.4 \mid$ & -1.23 & -1.57 & 1.33 \\
\hline P_10 & Aryl hydrocarbon receptor & 1.35 & - & 1.32 & 1.80 & 1.47 & -2.32 \\
\hline CA367764 & Calmodulin-I & - & -2.13 & -1.26 & -1.29 & -1.73 & 1.49 \\
\hline CA348284 & CCAAT/enhancer binding protein beta & -7.36 & -3.22 & -3.05 & - & -2.16 & 1.76 \\
\hline CA363762 & Cell death activator CIDE-B & 1.32 & - & 1.35 & 1.74 & 2.08 & -2.53 \\
\hline CA383564 & Coatomer epsilon subunit I & 2.25 & - & 1.20 & 1.43 & 1.24 & 1.53 \\
\hline HK0003_G0I & Creatine kinase, $M-2$ & - & 1.61 & -2.02 & 1.32 & -1.54 & -1.40 \\
\hline HK0002_G02 & Creatine kinase, sarcomeric mitochondrial precursor & -1.68 & - & 4.49 & -1.54 & -1.82 & 1.20 \\
\hline CA358998 & Cysteine-rich protein I & -1.75 & -2.71 & -1.37 & -1.51 & -1.62 & 2.75 \\
\hline utu0 Ig04 & Cytochrome oxidase subunit III-2 & - & -1.36 & -2.55 & -2.04 & -2.08 & 2.33 \\
\hline EXOBI_CIO & Cytochrome P450 2K4-2 & 1.60 & 1.34 & 1.20 & -1.44 & - & -1.14 \\
\hline utu0Id06 & Deoxyribonuclease gamma precursor & 1.50 & - & -1.19 & -1.26 & 1.46 & -1.31 \\
\hline utu0le09 & Embryonic alpha-type globin2+collagen alpha $2(\mathrm{I})$ & -1.62 & 1.42 & 4.94 & $-1.4 \mid$ & -1.96 & - \\
\hline HK000I_DI2 & Estrogen-responsive B box protein & 1.29 & - & -1.22 & -1.14 & 2.11 & -1.38 \\
\hline HK0002_G04 & Fructose-bisphosphate aldolase $\mathrm{A}$ & 1.65 & - & 1.25 & 2.45 & 3.59 & -4.80 \\
\hline HK000I_AII & Fumarate hydratase, mitochondrial precursor & - & -1.58 & -1.12 & -1.21 & 1.43 & -1.25 \\
\hline CA37I363 & Glucose-6-phosphate isomerase-I & -4.35 & -1.68 & -1.40 & -1.15 & -1.37 & 2.81 \\
\hline EXOB3_H05 & Glucose-6-phosphate isomerase-2 & -2.07 & - & $-|.5|$ & -2.08 & -1.77 & 1.81 \\
\hline CA366403 & Heat shock 27 kDa protein-I & 1.44 & - & 1.21 & 1.61 & 2.49 & -2.43 \\
\hline HST000I_C04 & Hemoglobin alpha chain & -2.42 & - & 11.19 & -1.82 & -2.93 & 2.87 \\
\hline EXOB2_B10 & Hemoglobin beta chain & -1.86 & - & 19.46 & -2.07 & -2.45 & 9.58 \\
\hline EXOB4_CII & High affinity immunoglobulin gamma Fc receptor I precursor & - & 2.15 & -1.70 & -1.73 & -1.88 & 1.71 \\
\hline est02all & Ig kappa chain V-IV region BI7-2 & 2.71 & - & 3.19 & -2.07 & -4.84 & 10.06 \\
\hline est02g07 & Ig mu heavy chain disease protein & 2.73 & - & 2.38 & 1.56 & -2.14 & 5.44 \\
\hline EXOB2_D05 & Matrix metalloproteinase $9-2$ & -6.63 & -2.62 & -3.07 & 1.71 & -1.93 & 3.20 \\
\hline EXOB3_HOI & Matrix metalloproteinase-13 & -17.18 & -5.88 & -1.32 & 2.06 & 1.44 & 4.34 \\
\hline est03c04 & Matrix metalloproteinase- 9 & -7.44 & -2.21 & -2.70 & 1.68 & -2.92 & 5.91 \\
\hline EXOB3_F09 & MHC class I heavy chain-I & - & 1.71 & -1.43 & -1.20 & -2.87 & -3.02 \\
\hline P_4 & Myeloperoxidase & 1.55 & - & 1.23 & 1.88 & 2.32 & -3.19 \\
\hline EXOB3_E09 & $\mathrm{N}$-myc downstream regulated protein-2 & -1.48 & 1.67 & 1.16 & 1.21 & - & -1.32 \\
\hline EXOB2_G02 & Profilin-I & - & -2.04 & -1.79 & -2.13 & -2.12 & 4.00 \\
\hline est02f08 & Serine protease-like protein-I & -2.97 & -4.64 & -3.21 & 1.32 & -1.84 & 6.41 \\
\hline ESTI-3A_A09 & Serine protease-like protein- 2 & -3.96 & -5.52 & -3.25 & 1.32 & -2.91 & 3.75 \\
\hline HK0002_H08 & TATA-binding protein associated factor $2 \mathrm{~N}$ & 1.79 & - & -1.32 & -1.22 & 1.71 & -1.32 \\
\hline est0le02 & Thymosin beta-4-I & - & -2.73 & -2.03 & -1.32 & -1.47 & 5.17 \\
\hline est0lelo & Tolloid-like protein (nephrosin)-I & -6.69 & -12.97 & -2.60 & -1.07 & -3.11 & 2.98 \\
\hline EXOB2_GI2 & Tolloid-like protein (nephrosin)-2 & -9.26 & -13.47 & -1.67 & 1.44 & -1.75 & 3.70 \\
\hline Hete0002_E09 & Transposase- 56 & 2.06 & 1.96 & 1.42 & 1.30 & 2.04 & 1.67 \\
\hline ESTI-3A_FI2 & Transposase-59 & 2.12 & 1.62 & 1.28 & 1.23 & - & 1.20 \\
\hline EXOB3_FII & Ubiquitin-conjugating enzyme E2-18 kDa & - & 1.47 & 1.48 & 1.68 & 1.61 & -1.84 \\
\hline
\end{tabular}

putative functions of extracellular TB4X include induction of hemostasis, wound and tissue healing, chemotaxis, induction of metalloproteinases, granulocyte-mediated inhibition of inflammatory processes and regulation of hematopoietic stem cell proliferation [62]. Not surpris- ingly, the TBX4 gene is $>2$ fold down regulated in trout HK $72 \mathrm{~h}$ post injection of LPS (table 1), but strongly upregulated ( $>5-7$ fold) in IHNV infected trout undergoing an incipient hemorrhagic symptomology. This suggests that, in fish as in mammals, the pleiotropic effects of TBX4 are 
Table 5: Genes specific to viral treatments. Genes selected were expressed in a minimum of 3 of the 4 experiments and compared against all experiments in the database $(n=155)$. Only genes specific to these experiments were chosen (Fischer's exact Test, $p<$ 0.001 ). Values are expressed as FC, fold change. 13 Unknowns were removed.

\begin{tabular}{|c|c|c|c|c|c|}
\hline \multirow[t]{2}{*}{ Clone ID } & \multirow[t]{2}{*}{ Clone Name } & \multicolumn{2}{|c|}{ AttIHNV (FC) } & \multicolumn{2}{|c|}{ IHNV (FC) } \\
\hline & & $24 \mathrm{hr}$ & $72 \mathrm{hr}$ & $24 \mathrm{hr}$ & $72 \mathrm{hr}$ \\
\hline CA387866 & Arachidonate 5-lipoxygenase-2 & 1.16 & 1.34 & 1.27 & 1.03 \\
\hline CA384555 & B-cell-specific coactivator OBF-I & 1.48 & 1.76 & 1.37 & -1.09 \\
\hline CA343473 & C3a anaphylatoxin chemotactic receptor & 3.00 & 2.98 & 5.35 & -1.50 \\
\hline ENH2_F03 & Cathepsin K-I & -2.30 & 1.22 & -3.01 & 1.42 \\
\hline EXOB4_F03 & Cathepsin S & -1.46 & -1.28 & -1.65 & 2.80 \\
\hline CA376117 & CD231 & 1.31 & 1.55 & 2.04 & -1.66 \\
\hline CA363762 & Cell death activator CIDE-B & 1.35 & 1.74 & 2.08 & -2.53 \\
\hline EXOB4_E08 & Cytochrome c oxidase subunit Vlla-related & 1.08 & -1.14 & 1.18 & -2.47 \\
\hline $\mathrm{CA} 381440$ & Double-stranded RNA-specific adenosine deaminase & 1.45 & 1.53 & 1.69 & -1.67 \\
\hline CA351392 & Guanine nucleotide exchange factor DBS & 1.19 & 1.93 & 2.97 & -3.13 \\
\hline EXOB4_CII & High affinity immunoglobulin gamma Fc receptor I precursor & -1.70 & -1.73 & -1.88 & 1.71 \\
\hline HKTOOOI_AII & Hypothetical-fish II & 1.20 & 2.28 & 1.49 & -1.85 \\
\hline est03c07 & Ig kappa chain V-I region WEA & 1.60 & 2.07 & 1.41 & 1.21 \\
\hline est02g07 & Ig mu heavy chain disease protein & 2.38 & 1.56 & -2.14 & 5.44 \\
\hline CA363978 & Inhibitor of kappaB kinase gamma & 1.16 & 2.13 & 2.21 & -2.36 \\
\hline EXOB3_F09 & MHC class I heavy chain-I & -1.43 & -1.20 & -2.87 & -3.02 \\
\hline CA34I859 & Nuclear factor NF-kappa-B & 1.40 & 1.12 & 1.63 & 1.28 \\
\hline CA378435 & Protein phosphatase $2 \mathrm{C}$ delta isofor & 1.44 & 2.05 & 3.35 & -3.87 \\
\hline EXOBI_B07 & PRPF39 protein & 1.19 & 1.22 & 1.39 & \\
\hline est03elo & Putative inorganic polyphosphate/ATP-NAD kinase & -1.11 & -1.05 & 1.33 & 1.29 \\
\hline est03b|2 & Secretory granule proteoglycan core protein & -1.83 & -1.83 & -2.97 & 2.77 \\
\hline $\mathrm{ENH} 2 \_\mathrm{B} 08$ & Splicing factor, arginine/serine-rich 8 & 1.10 & 1.24 & 1.25 & -1.49 \\
\hline CA380121 & Telomerase reverse transcriptase & 1.33 & 1.36 & 1.34 & -1.33 \\
\hline EXOBI_GI2 & Thioredoxin & -1.24 & $-1.6 \mid$ & -1.56 & 1.46 \\
\hline CA342204 & TNF receptor associated factor & 1.23 & 2.33 & 2.64 & -2.89 \\
\hline CA378736 & Tyrosine-protein kinase BTK & 1.28 & 1.61 & 1.81 & -1.80 \\
\hline EXOB3_G04 & Tyrosine-protein kinase HCK & -1.07 & -1.38 & -1.39 & 1.40 \\
\hline P_54 & VEGF4 & 1.23 & 1.34 & 1.37 & \\
\hline
\end{tabular}

mediated by the remodeling of intracellular actin cytoskeleton and/or components of the extracellular matrix [63].

The moderate/severe down-regulation of CXCR4 1 day post LPS challenge ( -3.7 fold change), metalloproteinases and TB4X observed at $24 \mathrm{~h}$ and $72 \mathrm{~h}$ (less than -6 and -2 fold change levels, respectively; table 1) thus favors a scenario of delayed reactive state to LPS stimulation in the recirculation and traffic of trout head kidney hematopoietic cells following i.p. administration of bacterial LPS. Moreover, the head kidney itself shows a low level stromal extracellular matrix remodeling in trout treated with LPS, as suggested by the down regulated expression of actin, MMP, nephrosins and Thymosin beta 4 (table 1). However, at 3 days post IHNV infection the transcriptomic footprints in the head kidney reveal an immunological shift orientated toward a somewhat impaired adaptive arm activation coupled with a strong hemostatic and extracellular matrix sculpting response: the systemic spreading of IHNV clearly inhibits TNFalpha, MHC class I and several macrophage and cell cycle/differentiation markers (tables 3, 4; see below) favoring a MHC class II, immunoglobulin and MMP/TBX4 enhanced immune response.

\section{Complement response to LPS-induced and viral challenges in trout head kidney}

Contrary to the liver, the head kidney cannot be considered an acute phase reactive organ. Following a xenobiotic assault, complement related serine proteases, modulators and C3 proteolytic peptides are synthesized primarily in the liver. However, minor but biologically significant extra-hepatic (mainly in active immune cells, gills, skin, heart, gonad and renal tissues) synthesis of complement components has recently been demonstrated in fish as in other vertebrates $[64,65]$. Therefore, complement inflammatory, chemotactic, opsonic and lytic activities extend the effect of the innate arm of immune responses to the core of major hematopoietic organs.

In trout injected with LPS, complement related serine proteases (spl1 and spl2) homologous to the MASP proteins involved in the activation of the classical complement 
pathway $[66,67]$ remained down regulated throughout the treatment ( -3 and -4 fold change at $24 \mathrm{~h}$ and $72 \mathrm{~h}$ respectively; table 1 ) and no expression of $\mathrm{C} 3$ genes were detectable in head kidney (table 1), in concordance with the biased adaptive response observed in this group (see below). A recent microarray analysis of acute phase reactivity in the liver of catfish (Ictalurus punctatus) showed an enhanced (greater than $>2$ fold) complement response in fish infected with Edwardsiella ictaluri, a gram negative pathogen responsible for enteric septicemia in catfish [13] In trout, Lovoll et al. (2007b) found a similar expression pattern in hepatocytes treated with LPS, but, in sharp contrast with the highest expression levels of complement genes in liver, a minor up regulation of $\mathrm{C} 3$ genes in head kidney and spleen was observed. Additionally, gene expression showed a strong tissue and isoform dependence: C3-4 was found to be down regulated in HK following stimulation with LPS, and more interestingly, not all trout isoforms maintained similar levels of gene expression [68].

The tolerance of fish to the standard LPS doses used in rodent immune challenges is well known, and has been linked to the peculiarities of PAMP receptors in fish [36] that may preclude a strong endotoxic shock response. Thus, the strongest cellular and tissue responses to i.p. injection LPS in fish are thought to be restricted to activated monocyte/macrophages and lymphocytes, portals of entry (gills, intestine, skin) and acute phase organs (liver). However, the dynamics of the teleostean immune response is of primary interest in these organs, as in the head kidney, that functions either as a cradle for immunological priming of leukocyte populations or as a major node in the complex and the still poorly understood network of neuro-immune-endocrine interactions in fish. In that respect, our results uncover a striking difference between lipopolysaccharide and viral treatments concerning head kidney transcriptomic dynamics: in attenuated and active IHNV groups, the complement related serine proteases and anaphylatoxin receptors $(\mathrm{C} 3 \mathrm{aR})$ maintain up regulated expression levels at both time points, with the maximal expression ( $>5-6$ fold change) in active viral groups.

The C3aR shows an unequivocal upregulated expression at $24 \mathrm{~h}$ and $72 \mathrm{~h}$ in animals infected with attIHNV, and at $24 \mathrm{~h}$ in animals infected with active IHNV (our results also show a tenuous down regulation of C3aR (-1.5 fold change) in IHNV treated fish at $72 \mathrm{~h}$; see additional file 1 ). At $72 \mathrm{~h}$, the response to IHNV consist of a mixture of adaptive (MHC, IG) and innate (C3aR, complement related serine proteases, lysozyme $\mathrm{C}$ ) immune and stress (HSP70, hemostasis) responses against a background of metalloproteinase-mediated matrix remodeling (table 3 ). Therefore, as suggested in this and previous studies with mammals [69-71], the expression of C3a/C3aR may probably contribute to the homing/mobilizations and differentiation of hematopoietic stem cells in response to the generalized immune and stress response elicited by an aggressive and extremely pathogenic virus in fish. Moreover, in mammals several C3 cleavage fragments, including C3a has been demonstrated to be linked to the CXCR4mediated responsiveness of hematopoietic stem cells [71]. The moderate down regulation of CXCR4 in LPS treated fish (table 1) and upregulation ( $>1.5$ fold) in attIHNV infected fish (see additional file 1), together with the strong upregulation of C3aR in IHNV treated fish suggests a conservation of complement mediated functional responses in the hematopoietic head kidney. The dynamics and trafficking of hematopoietic and differentiated cells in fish are, nonetheless, far from being fully understood.

\section{Specific immune responses to LPS-induced and viral challenges in trout head kidney}

Genes involved in the immunoglobulin system increased in all treatments displaying different kinetics. Ig gamma Fc receptor (CD64) gene expression increased late in the LPS treatment whereas IgM heavy chain (B-cells) and Ig kappa chain V-IV region B17-2 (involved in antigen presentation) increased acutely. Under attIHNV conditions a similar regulation is observed for the latter genes in which IgM expression is sustained at 72 hours and Ig Kappa suppressed. CD64 expression is suppressed by attenuated virus, whereas IHNV suppresses all three genes at the early stage and induces expression $(1.7,10$ and 5.4 fold respectively) at the later stage of infection. This may reflect migration of leukocytes to the primary sites of infection/ inflammation and/or differential recruitment of leukocyte sub-populations to the infected head kidney in both IHNV/attIHNV treatments.

The coatomer protein (COP) epsilon known to play a role in the formation and maturation of phagosomes [72] is induced in all treatments, and the Class I major histocompatibility complex (MHC) antigen, well known to be involved in antigen presentation in dendritic cells is activated late by LPS and suppressed by viral treatments $(-3$ fold; tables 2, 3), whereas Class II MHC showed a moderate up regulation ( 4.4 fold) in fish infected with IHNV at $72 \mathrm{~h}$.

In fish, as in mammals, the interaction of MHC molecules with $\mathrm{T}$ cell receptors (TCR) seems to activate subsets of cytotoxic T lymphocytes (CTL) and T helper cells (Th) in a similar fashion [73]. Homologues of mammalian MHC, several proteins associated to antigen presentation, beta2 microglobulin and CD8+ and CD4+ (markers for CTL and Th, respectively) have been recently characterized in trout and other fish species $[74,75]$, thus reinforcing the conser- 
vation of antigen processing pathways in immune cells. However, the trafficking, recirculation and cell-to-cell communication against a quiescent/activated immune background have not yet been properly described in fish. Moreover, the translation of classical bacterial or viral inflammatory murine models encompasses several technical (full characterization of immune processes, absence/ presence of mediators, conservation of activation/inhibition pathways) and species-specific difficulties, the latter related to the high variability of the interspecific thresholds of immune activation in fish and, last but not least, the relative virulence and co-evolutionary trade-offs of pathogens.

Our and several recent studies have attempted to resolve these issues weighting the organ related immune response to an established model of LPS-induced inflammation or viral infection. In this regard, the expression of CD8 and CD4 (coreceptors of MHC Class I and II binding, respectively) in trout seems to be restricted mainly to thymus and to a certain extent, to spleen, even though noninfected fish maintain a widespread low level expression in several hematopoietic or lymphocyte infiltrated organs $[74,75]$. Overturf and LaPatra (2006) were unable to find elevated levels of CD8 expression in the HK of trout infected with bacteria or IHNV at 24 h or 5 days post infection, although in liver and spleen a positive dose-response correlation followed the infection $(24 \mathrm{~h})$ expression of CD8 and C3 [76]. In a similar experiment, 72 hours after IHNV challenge Hansen and LaPatra (2002) observed a surprising tissue-specific shutdown of MHC Class IIB mRNA in head kidney and spleen of infected trout, thus suggesting an enhanced CD8 response coupled with activation of MHC Class I antigen presentation following IHNV infection [77], as observed in a cohabitant model of fish viral infection described recently [78]. Similarly, an infection by Vibrio anguilarum seemed to depress the short term (up to 4 days) expression of MHC class II genes in head kidney, liver and spleen of turbot, Scophthalmus maximus [79]. However, an elevated expression of MHC Class II genes has been described in trout following i.m. DNA vaccination with recombinant IHNV [80] and xenobiotic inflammation [81]. In trout challenged with VSHV, a member of Rhabdoviridae, the dynamics of T cell expansion, and thus the onset of MHC mediated adaptive immune response, were found to be correlated with the expected waves of viral replication, with peak a week after viral challenge [82], mimicking the delayed (up to 10 days) expression of MHC mRNAs that were also observed in japanese flounder (Paralichthys olivaceus) leukocytes infected with Neoheterobothrium hirame, a monogenean parasite [83].

As described in other species [84,85], our results suggest a predilection for CD4/Th lymphocyte response in the head kidney of trout challenged with IHNV at 72 post infection, coupled with a strong spl-induced complement cleavage activation and MMP/TBX4 extracellular matrix sculpting, together with a decreased TNFalpha mediated activation of monocyte/macrophage populations, a shutdown of MHC Class I and also a low level regulation of apoptosis, as shown by the inhibition of Ubiquitin ligase S1AH1 and Galectin-9 (see table 3 and additional file 1).

The i.p. administration of LPS activates the MHC Class I pathway of antigen processing in concordance with previous studies with LPS-activated trout macrophages [8]. However, the transcription factor CCAAT/enhancer binding protein-alpha (C/EBP-alpha), best known for its role in driving myeloid cells towards the granulocytic line [86] but also known to be induced during macrophage differentiation, and the MMP/TBX4 response was inhibited in head kidney $72 \mathrm{~h}$ post injection. Deltex protein 1 (DTX) also appears to be down regulated $72 \mathrm{~h}$ post infection with LPS (table 1). Although still poorly understood, the cross-talk between Deltex protein 1 (DTX1) and the evolutionary conserved Notch and NFkappaB signaling pathways $[87,88]$ allows the normal development and maturation of differentiated lymphocyte populations in hematopoietic and lymphopoietic organs in mammals. This suggests an impaired trafficking of lymphoid/myeloid HK cells in the early response to LPS in trout.

Myeloperoxidase (MPO) was up-regulated by all treatments at 24 hours returning to baseline in LPS samples, increasing in attIHNV and actively inhibited in IHNV samples (tables 1, 2, 3, 4). Myeloperoxidase is expressed in neutrophils and monocytes and plays a role in the oxygen dependent mechanism of phagocytosis. The macrophage scavenger receptor MARCO [89] was also inhibited in IHNV samples. Therefore, the microbiocidal function was diminished in the head kidney of IHNV infected trout.

Taken together, these results may suggest a minor function of the head kidney in the short term (24-72 hrs) activation of the immune response to virulent IHNV, or, alternatively, an inducible and maybe antagonistic early differential expression of MHC Class I or II mediated antigen processing in the head kidney, heavily influenced either by the type and infective dynamics of pathogen (LPS vs. viral) or the portals of entry (organ/tissue). From the experimental infections described above, the liver and spleen also seem to act as a major acute phase reactive organs at the initial stages of viral invasion, and the head kidney can be more properly defined as an inductor of a delayed adaptive response as much as a major regulator of erythropoietic and myeloid differentiation. Nevertheless the dual expression of the MHC antigen processing/presenting machinery appears to be strongly influenced by 
the species-specific immunological sensibility [90,91], the virulence of pathogens and the timing of cellular differentiation in immune organs. This pathogen/host speciesspecific branching of MHC mediated immune response in fish requires, however, further analysis.

\section{Haemoglobin metabolism in LPS-induced and viral infected trout head kidney}

Hemoglobin genes $(\alpha, \beta)$ are suppressed by both LPS and IHNV at 24 hours, $2-3$ fold suppression, however attIHNV strongly induces expression of both proteins (11 and 19 fold respectively) followed by suppression at 72 hours. IHNV induces expression ( 3 and 10 fold $\alpha$ and $\beta$ respectively) at 72 hours whereas LPS samples return to baseline levels.

Interestingly, 5-aminolevulinate synthase, the key enzyme involved in heme synthesis was up-regulated in both attIHNV samples and in a LPS-specific manner at 72 hours. A similar response has been observed in head kidney tissue from Atlantic salmon, $S$. salar, infected with Piscirickettsia [15].

The coordinated expression of both hemoglobin genes and 5-aminolevulinate synthase suggest erythropoietic activity in the head kidney. Furthermore, a significant increase in cellular proliferation in PU-1-ve cells, 72 hours post-LPS administration, in the head kidney of LPStreated rainbow trout has been reported (Ribas et al, 2007 in press) thus activation of hematopoietic, potentially erythropoietic, mechanisms during the early stages of infectious processes may be a standard for the non-specific immune response in fish.

\section{HSP induced stress response to LPS-induced and viral challenges in trout head kidney}

Active IHNV inhibits the expression of heat shock protein (HSP) 27 (-2.4 fold) and induces the expression of 70 and 90 (2.8 and 2.3 fold respectively) 3 days post infection from a previous inactive state at $24 \mathrm{~h}(-4.24$ fold). The attIHNV showed a down regulation of HSP70 ( -2 fold $)$ at the same time point.

HSPs have been implicated in the generalized stress response associated to xenobiotics and/or inflammatory reactions in fish $[44,85,92]$. However, the reliability of HSP as an indicator of stress or pathologic/immune disturbances has recently thoroughly criticized [93] because of the great variability of measured HSP expression: despite the correlated expression of HSP with altered states in stressed or injured fish, the sensitivity and intensity of HSP response can vary in a species-specific manner, and among tissues, HSP families, season, developmental stages and stressor. Not being an acute phase response organ, it is, thus, difficult to speculate about the fate of
HSP repaired enzymatic and/or cytoskeleton proteins in infected head kidney.

\section{Conclusion}

For the functional analysis of biological roles of regulated genes, our two-step approach in the first instance establishes a list of differentially expressed genes whose ascribed biological roles are evaluated and secondly by identifying overrepresented GO functional categories using the KuopioChip analysis software (see materials and methods). This methodological approach is not exempt of limitations. The selected cut-offs for minimal gene expression, the co-expressed patterns of gene expression, the non lineal genome-proteome crosstalk and the limited transcript enrichment of the array can either limit the amount and quality of transcriptomic responses assessed or exclude transient but biologically relevant genetic responses correlated with the abruptness and organ-dependent systemic damage in infected fish.

As a guideline for elucidating the biological response of viral/LPS-induced challenge, the comparison of differentially expressed genes by the GO categories showed a marked induction of metalloproteinases and other collagen and extracellular matrix sculptors in LPS treated trout, coupled with a decrease in genes controlling the basal metabolism and an increase in the activity of immune related mediators of MHC antigen presenting and immunoglublin-mediated opsonisation (figures 2 and 5) $72 \mathrm{~h}$ post infection.

Several genes involved in signal transduction and protein biosynthesis were active in attIHNV groups $72 \mathrm{~h}$ post infection, following a decrease in cytoskeleton remodelling. As in active IHNV infected trout, the functional GO categories are strongly enriched in genes active during inflammatory, immune and defence responses. In both attenuated and active IHNV treated fish, the immune response at $72 \mathrm{~h}$ clearly outweighs the metalloproteinase orientated LPS response, but, as described above, the response of the trout head kidney transcriptome to IHNV infection was more robust and diversified in number and immune related activation pathways.

\section{Methods}

\section{Animal protocol an experimental infections}

Rainbow trout, Oncorhynchus mykiss, were obtained from two commercial fish farms. Fish were maintained in flow through tanks under ambient conditions of light (photoperiod $10 \mathrm{~L} / 14 \mathrm{D})$ and temperature $\left(15 \pm 2{ }^{\circ} \mathrm{C}\right)$. Fish were fed with commercial trout pellets ad libitum and acclimated for at least two weeks prior to use in experiments. The health status of the animals and water quality were checked on a daily basis. Challenge experiments were carried out separately for each treatment and were 
performed in recirculating tanks with aeration at $14^{\circ} \mathrm{C}$ Trout ( $\mathrm{n}=10 /$ tank) weighing between $70-100 \mathrm{~g}$ were separated into 6 different tanks, 3 control and 3 experimental tanks. For experimental stimulations the fish were mildly anaesthetized (MS-222, $40 \mathrm{ppm}$, stage II of anaesthesia according to Iwama et al. 1989) and intraperitoneal (i.p.) injections carried out. Fish were intraperitoneally injected with saline (control) and LPS (6 mg/Kg; serotype 026:B6, Sigma, \#L-8274), or with $100 \mu \mathrm{l}$ of a $10^{6} \mathrm{pfu} / \mathrm{ml}$ dilution of IHNV or attIHNV or culture medium (negative control). At defined time points, 24 and 72 hours post i.p. injection, animals (total $\mathrm{n}=6$ ), control and experimental, were selected from each tank $(n=2)$ and sacrificed by over anesthetization (MS-222, 100 ppm, stage III of anaesthesia [94]). Head kidneys (HK) were immediately dissected out, pooled and processed for total RNA purification using Tri Reagent (Molecular Research Center, Cincinnati, $\mathrm{OH}$, USA) according to the manufacturer's protocol $[95,96]$.

\section{Viruses and cell line}

IHNV (French isolate 32/87) was used and propagated in the fish epithelial cell-line EPC derived from common carp (Cyprinus carpio) [97]. EPC cells were cultured in Eagle's minimum essential medium (MEM, Gibco) supplemented with foetal bovine serum (FBS), penicillin (100 IU ml-1), streptomycin $\left(100 \mu \mathrm{g} \mathrm{ml}^{-1}\right)$, buffered with $7,5 \%$ sodium bicarbonate and incubated at $20^{\circ} \mathrm{C}$. The virus was inoculated on EPC grown in MEM with antibiotics and $2 \% \mathrm{FCS}$ at $14^{\circ} \mathrm{C}$. When the cytopathic effect was complete, the supernatant was harvested and centrifuged to eliminate cell debris. The virus stock was titrated according to Reed \& Muench [98] in EPC 96 well plates. Attenuated IHNV was generated by reverse genetic engineering of virulent IHNV by M. Bremont as described elsewhere [31].

\section{RNA isolation}

RNA from head kidneys of experimental and control/ sham-injected fish were extracted with the Trizol reagent (Life Technologies) or Tri Reagent (Molecular Research Center, Cincinnati, OH, USA) according to the manufacturer's instructions. DNase treatment was performed to remove contaminating DNA from preparations. RNA was precipitated using ethanol $100 \%$ and ammonium acetate (pH 5.2). The RNA was stored at $-80^{\circ} \mathrm{C}$ in ethanol $70 \%$ until use.

\section{Microarray design and analyses}

The design of the microarray is described in detail elsewhere $[6,7]$ and a full description of the platform and data presented in this manuscript are accessible through the public GEO depositories (accession number GPL6155 and GSE10272). In brief, the platform included 1380 genes printed in six replicates each. Random clones from common and subtracted cDNA libraries (976) were compared with the known vertebrate proteins using blastx and 686 genes were identified; the functional annotations were transferred from the putative homologs. These clones were supplemented with 297 genes selected by the categories of Gene Ontology. Overall, each microarray was enriched in a number of functional classes, such as stress and defense response (145 and 105 genes, respectively), cell cycle (62 genes), signal transduction (114 genes), chaperone activity (41 genes), and apoptosis (79 genes).

Total RNA obtained from head kidney tissue was verified for quantity and integrity by denaturing electrophoresis and labeling with Cy3- and Cy5-dCTP (Amersham Pharmacia) was completed using SuperScript III reverse transcriptase (Invitrogen) and oligo(dT) primer, and cDNA was purified with Microcon YM30 (Millipore). We used a dye swap experimental design [99] and each sample was hybridized to two microarrays. For the first slide, test and control cDNA were labeled with Cy5 and Cy3 respectively, and for the second array dye assignment was reversed. All head kidney samples were analyses using the dye swap protocol. The slides were pre-treated with $1 \%$ BSA, fraction V, $5 \times \mathrm{SSC}, 0.1 \% \mathrm{SDS}\left(30 \mathrm{~min}\right.$ at $\left.50^{\circ} \mathrm{C}\right)$ and washed with $2 \times \operatorname{SSC}(3 \mathrm{~min})$ and $0.2 \times \operatorname{SSC}(3 \mathrm{~min})$ and hybridized overnight in cocktail containing $1.3 \times$ Denhardt's, $3 \times$ SSC $0.3 \%$ SDS, $2.1 \mu \mathrm{g} / \mu$ l polyadenylate and 1 $\mu \mathrm{g} / \mu \mathrm{l}$ yeast tRNA. All chemicals were from Sigma-Aldrich. Scanning was performed with ScanArray 5000 and images were processed with QuantArray (GSI Luminomics). The measurements in spots were filtered by criteria $I / B \geq 3$ and $(I-B) /\left(S_{I}+S_{B}\right) \geq 0.6$, where $I$ and $B$ are the mean signal and background intensities and $S_{I}, S_{B}$ are the standard deviations. After subtraction of mean background, locally weighted non-linear regression (Lowess) normalization [100] was performed separately for each slide. To assess differential expression of genes, the normalized log intensity ratios were analyzed with Student's t-test $(p<0.01)$. The Bayesian modification to the false discovery rate (FDR) was used to correct for multiple comparison tests, estimating the $q$-value for the set of differentially expressed genes [101]. For the analysis of the functional profiling of samples, all genes that showed significant differential expression $(p<0.01)$ in at least one sample were used. Due to the large number of genes, the statistical significance of over represented functional categories in each experiment (figs. 2, 3, 4) was assessed using the Yates correction to Chi square test (corrected $p<0.05)$. The log ( $p$ level) ranked up or down-regulated genes were analyzed interrogating the functional classes of Gene Ontology (GO) [102] and compared by the sums of ranked genes (Student's t-test, $\mathrm{p}<0.05)$. A list of LPS and virus specific responsive genes (figs 5, 6, 7) was obtained by GO data 
mining of a database (KuopioChip) of 155 previous immune and stress related experiments $[7,43]$.

\section{Quantitative RT PCR}

Primers were designed to amplify $194-305$ bp fragments. RNA was processed with Rnase-free Dnase (Promega). Synthesis of cDNA with Superscript III reverse transcriptase (Invitrogen) was primed with oligo(dT). Analyses were carried out using Dynamo SYBR Green kit (Finnzymes) and ABI Prism 7700 (Amersham-Pharmacia)

In order to quantify mRNA expression, real time PCR (QPCR) was carried out. CDNA was diluted 1:50 for target mRNA and 1:100 for $18 \mathrm{~S}$ and used as a template with the primers Q-PCR Fw and Q-PCR Rv (see additional file 1, table 7). Wells (20 $\mu \mathrm{l}$ final volume) contained $10 \mu \mathrm{l}$ of $\mathrm{iQ}^{\mathrm{TM}}$ SYBR Green Supermix (Bio-Rad), $500 \mathrm{nM}$ concentration of forward and reverse primers and $5 \mu \mathrm{l}$ of cDNA. Controls lacking cDNA and controls containing RNA were included. Reactions were run in a MyiQ thermocycler (BioRad) under the following protocol: $5 \mathrm{~min}$ initial denaturation at $95^{\circ} \mathrm{C}$, followed by 40 cycles of $10 \mathrm{sec}$ denaturation at $95^{\circ} \mathrm{C}$ and $30 \mathrm{sec}$ at $60^{\circ} \mathrm{C}$, and a final melting curve of 81 cycles (from $55^{\circ} \mathrm{C}$ to $95^{\circ} \mathrm{C}$ ). All samples were run in triplicate and fluorescence was measured at the end of every extension step. $\mathrm{C}_{\mathrm{T}}$ (threshold cycle) values for each sample were expressed as "fold differences", calculated relative to untreated controls and normalized for each gene against those obtained for $18 \mathrm{~S}$ (see additional file 1, Table 8).

\section{Authors' contributions}

$\mathrm{AF}, \mathrm{BN}, \mathrm{SM}, \mathrm{JCB}$, and LR performed the experimental viral and LPS stimulations. AK carried on the microarray hybridizations and quality control. NR performed the qRT-PCR. SM and JCB performed the statistical analysis of all microarray data sets and drafted the manuscript. All authors read and approved the manuscript.

\section{Additional material}

\section{Additional file 1}

IHNV-LPS trout microarray design and genes. Design of microarray platform. List of genes selected for significant differences at 24 and 72 hours in LPS, attIHNV and IHNV treatments. QPCR validation of specific clones

Click here for file

[http://www.biomedcentral.com/content/supplementary/14712164-9-141-S1.doc]

\section{Additional file 2}

Microarray sequence clones. List of annotated sequence clones. Click here for file

[http://www.biomedcentral.com/content/supplementary/14712164-9-141-S2.xls]

\section{Acknowledgements}

This work was supported by Plan Nacional AGL2005-12134 from the Ministerio de Educación y Ciencia, España and the EU-funded project IMAQUANIM, EC contract number FOOD-CT-2005-007I03.

\section{References}

I. Bianchi ME: DAMPs, PAMPs and alarmins: all we need to know about danger. Journal of leukocyte biology 2007, 8 I (I): I-5.

2. Sepulcre MP, Lopez-Castejon G, Meseguer J, Mulero V: The activation of gilthead seabream professional phagocytes by different PAMPs underlines the behavioural diversity of the main innate immune cells of bony fish. Molecular immunology 2007 , 44(8):2009-2016.

3. Zhong J, Kyriakis JM: Dissection of a signaling pathway by which pathogen-associated molecular patterns (PAMPs) recruit the JNK and p38 MAPKs and trigger cytokine release. J Biol Chem 2007, 282(33):24246-54.

4. Giri MS, Nebozhyn M, Showe L, Montaner LJ: Microarray data on gene modulation by HIV-I in immune cells: 2000-2006. Journal of leukocyte biology 2006, 80(5): I03 I- 1043.

5. Li J, Pritchard DK, Wang X, Park DR, Bumgarner RE, Schwartz SM, Liles WC: cDNA microarray analysis reveals fundamental differences in the expression profiles of primary human monocytes, monocyte-derived macrophages, and alveolar macrophages. Journal of leukocyte biology 2007, 8 I (I):328-335.

6. Koskinen H, Pehkonen P, Vehniainen E, Krasnov A, Rexroad C, Afanasyev $\mathrm{S}$, Molsa $\mathrm{H}$, Oikari $\mathrm{A}$ : Response of rainbow trout transcriptome to model chemical contaminants. Biochemical and biophysical research communications 2004, 320(3):745-753.

7. Krasnov A, Koskinen H, Pehkonen P, Rexroad CE 3rd, Afanasyev S, Molsa $\mathrm{H}$ : Gene expression in the brain and kidney of rainbow trout in response to handling stress. BMC genomics 2005, 6(I):3.

8. MacKenzie S, Iliev D, Liarte C, Koskinen H, Planas JV, Goetz FW, Molsa H, Krasnov A, Tort L: Transcriptional analysis of LPSstimulated activation of trout (Oncorhynchus mykiss) monocyte/macrophage cells in primary culture treated with cortisol. Molecular immunology 2006, 43(9): I340-1348.

9. Iliev DB, Liarte CQ, MacKenzie S, Goetz FW: Activation of rainbow trout (Oncorhynchus mykiss) mononuclear phagocytes by different pathogen associated molecular pattern (PAMP) bearing agents. Molecular immunology 2005, 42(10): I 2 I5- 1223.

10. Byon JY, Ohira T, Hirono I, Aoki T: Use of a CDNA microarray to study immunity against viral hemorrhagic septicemia (VHS) in Japanese flounder (Paralichthys olivaceus) following DNA vaccination. Fish Shellfish Immunol 2005, I 8(2): | 35-147.

II. Ewart KV, Belanger JC, Williams J, Karakach T, Penny S, Tsoi SC, Richards RC, Douglas SE: Identification of genes differentially expressed in Atlantic salmon (Salmo salar) in response to infection by Aeromonas salmonicida using cDNA microarray technology. Dev Comp Immunol 2005, 29(4):333-347.

12. Morrison RN, Cooper GA, Koop BF, Rise ML, Bridle AR, Adams MB Nowak BF: Transcriptome profiling the gills of amoebic gill disease (AGD)-affected Atlantic salmon (Salmo salar L.): a role for tumor suppressor p53 in AGD pathogenesis? Physiological genomics 2006, 26(I):15-34.

13. Peatman E, Baoprasertkul P, Terhune J, Xu P, Nandi S, Kucuktas H, Li $P$, Wang S, Somridhivej B, Dunham R, Liu Z: Expression analysis of the acute phase response in channel catfish (Ictalurus punctatus) after infection with a Gram-negative bacterium. Dev Comp Immunol 2007.

14. Purcell MK, Nichols KM, Winton JR, Kurath G, Thorgaard GH, Wheeler P, Hansen JD, Herwig RP, Park LK: Comprehensive gene expression profiling following DNA vaccination of rainbow 
trout against infectious hematopoietic necrosis virus. Molecular immunology 2006, 43(13):2089-2। 06.

15. Rise ML, Jones SR, Brown GD, von Schalburg KR, Davidson WS, Koop BF: Microarray analyses identify molecular biomarkers of Atlantic salmon macrophage and hematopoietic kidney response to Piscirickettsia salmonis infection. Physiological genomics 2004, 20(I):2I-35

16. Yasuike M, Kondo H, Hirono I, Aoki T: Difference in Japanese flounder, Paralichthys olivaceus gene expression profile following hirame rhabdovirus (HIRRV) G and N protein DNA vaccination. Fish Shellfish Immunol 2006.

17. Kasahara M, Naruse K, Sasaki S, Nakatani Y, Qu W, Ahsan B, Yamada T, Nagayasu Y, Doi K, Kasai Y, Jindo T, Kobayashi D, Shimada A, Toyoda A, Kuroki Y, Fujiyama A, Sasaki T, Shimizu A, Asakawa S, Shimizu N, Hashimoto S, Yang J, Lee Y, Matsushima K, Sugano S, Sakaizumi M, Narita T, Ohishi K, Haga S, Ohta F, Nomoto H, Nogata K, Morishita T, Endo T, Shin IT, Takeda H, Morishita S, Kohara Y: The medaka draft genome and insights into vertebrate genome evolution. Nature 2007, 447(7| 45):7|4-7/9.

18. Engelsma MY, Huising MO, van Muiswinkel WB, Flik G, Kwang J, Savelkoul HF, Verburg-van Kemenade BM: Neuroendocrineimmune interactions in fish: a role for interleukin- I. Veterinary immunology and immunopathology 2002, 87(3-4):467-479.

19. Kobayashi I, Sekiya M, Moritomo T, Ototake M, Nakanishi T: Demonstration of hematopoietic stem cells in ginbuna carp (Carassius auratus langsdorfii) kidney. Dev Comp Immunol 2006 , 30(I I): 1034-1046.

20. To TT, Hahner S, Nica G, Rohr KB, Hammerschmidt M, Winkler C Allolio $B$ : Pituitary-interrenal interaction in zebrafish interrenal organ development. Molecular endocrinology (Baltimore, Md 2007, 2 I (2):472-485.

21. Willett CE, Cortes A, Zuasti A, Zapata AG: Early hematopoiesis and developing lymphoid organs in the zebrafish. Dev Dyn 1999, 21 4(4):323-336.

22. Joerink M, Ribeiro CM, Stet RJ, Hermsen T, Savelkoul HF, Wiegertjes GF: Head kidney-derived macrophages of common carp (Cyprinus carpio L.) show plasticity and functional polarization upon differential stimulation. J Immunol 2006, I77(1):61-69.

23. Mackenzie S, Liarte C, lliev D, Planas JV, Tort L, Goetz FW: Characterization of a highly inducible novel CC chemokine from differentiated rainbow trout (Oncorhynchus mykiss) macrophages. Immunogenetics 2004, 56(8):6II-6I5.

24. Bootland LM, Leong JC: Infectious hematopoietic necrosis virus. Fish Diseases and Disorders, Volume 3: Viral, Bacterial and Fungal Infections, Woo PTK \& Bruno DW, eds CAB International, Oxon, UK 1999:57-121.

25. Hoffmann B, Beer M, Schutze H, Mettenleiter TC: Fish rhabdoviruses: molecular epidemiology and evolution. Current topics in microbiology and immunology 2005, 292:8I-I I 7.

26. Schutze H, Enzmann PJ, Kuchling R, Mundt E, Niemann H, Mettenleiter TC: Complete genomic sequence of the fish rhabdovirus infectious haematopoietic necrosis virus. The Journal of general virology 1995, 76 ( Pt 10):2519-2527.

27. Schutze H, Mundt E, Mettenleiter TC: Complete genomic sequence of viral hemorrhagic septicemia virus, a fish rhabdovirus. Virus genes 1999, 19(I):59-65.

28. Lee JY, Cho WJ, Do JW, Kim HJ, Park JW, Park MA, Sohn SG, Jeong G, Hah YC: Monoclonal antibodies raised against infectious haematopoietic necrosis virus (IHNV) G protein and a cellular $90 \mathrm{kDa}$ protein neutralize IHNV infection in vitro. The Journal of general virology 1996, 77 ( Pt 8): 1731-1737.

29. McAllister PE, Wagner RR: Structural proteins of two salmonid rhabdoviruses. Journal of virology 1975, 15(4):733-738.

30. Thoulouze MI, Bouguyon E, Carpentier C, Bremont M: Essential role of the NV protein of Novirhabdovirus for pathogenicity in rainbow trout. Journal of virology 2004, 78(8):4098-4107.

31. Biacchesi S, Thoulouze MI, Bearzotti M, Yu YX, Bremont M: Recovery of NV knockout infectious hematopoietic necrosis virus expressing foreign genes. Journal of virology 2000 , 74(23): I I 247-I I 253 .

32. Biering E, Villoing S, Sommerset I, Christie KE: Update on viral vaccines for fish. Developments in biologicals 2005, I 2 I:97-I I 3.

33. Lorenzen N, Lorenzen E, Einer-Jensen K, LaPatra SE: DNA vaccines as a tool for analysing the protective immune response against rhabdoviruses in rainbow trout. Fish Shellfish Immunol 2002, I 2(5):439-453.

34. Bishop RE: Fundamentals of endotoxin structure and function. Contributions to microbiology 2005, I 2: I-27.

35. Raetz CR, Whitfield C: Lipopolysaccharide endotoxins. Annual review of biochemistry 2002, 7 I:635-700.

36. Iliev DB, Roach JC, Mackenzie S, Planas JV, Goetz FW: Endotoxin recognition: in fish or not in fish? FEBS letters 2005, 579(29):6519-6528.

37. Amend DF, Yasutake WT, Mead RW: A haematopoietic virus disease of rainbow trout and sockeye salmon. Trans Am Fish Soc 1969:796-804.

38. Drolet BS, Rohovec JS, Leong JA: The route of entry and progression of infectious hematopoietic necrosis virus in Oncorhynchus mykiss (Walbaum): a sequential immunohistochemic study. J Fish Dis 1994:337-47.

39. Romero A, Figueras A, Tafalla C, Thoulouze MI, Bremont M, Novoa $B$ : Histological, serological and virulence studies on rainbow trout experimentally infected with recombinant infectious hematopoietic necrosis viruses. Diseases of aquatic organisms 2005, 68(I): 17-28

40. Wolf K: Infectious hematopoietic necrosis. In: Wolf K (ed) Fish viruses and fish viral diseases. Cornell University Press, Ithaca, NY,. 1988:83-I|4.

41. Yamamoto T: Multiplication of Infectious Hematopoietic Necrosis Virus in rainbow trout following immersion infection: Whole-body assay and immunohistochemistry. J Aquat Anim Health 1990:27I-280.

42. Yamamoto T, Batts WN, Arakawa CK, Winton JR: Multiplication of Infectious Hematopoietic Necrosis Virus in Rainbow Trout following Immersion Infection: Whole-Body Assay and Immunohistochemistry. J Aq Animal Health 1990 2(4):27I-280.

43. Krasnov A, Afanasyev S, Oikari A: Hepatic responses of gene expression in juvenile brown trout (Salmo trutta lacustris) exposed to three model contaminants applied singly and in combination. Environmental toxicology and chemistry / SETAC 2007 26(I): $100-109$

44. Purcell MK, Kurath G, Garver KA, Herwig RP, Winton JR: Quantitative expression profiling of immune response genes in rainbow trout following infectious haematopoietic necrosis virus (IHNV) infection or DNA vaccination. Fish Shellfish Immunol 2004, I 7(5):447-462.

45. Rodriguez MF, Wiens GD, Purcell MK, Palti Y: Characterization of Toll-like receptor 3 gene in rainbow trout (Oncorhynchus mykiss). Immunogenetics 2005, 57(7):510-519.

46. DiDonato JA, Hayakawa M, Rothwarf DM, Zandi E, Karin M: A cytokine-responsive lkappaB kinase that activates the transcription factor NF-kappaB. Nature 1997, 388(6642):548-554.

47. O'Donnell SM, Holm GH, Pierce JM, Tian B, Watson MJ, Chari RS, Ballard DW, Brasier AR, Dermody TS: Identification of an NF. kappaB-dependent gene network in cells infected by mammalian reovirus. Journal of virology 2006, 80(3): 1077-1086.

48. Hung CH, Huang HR, Huang CJ, Huang FL, Chang GD: Purification and cloning of carp nephrosin, a secreted zinc endopeptidase of the astacin family. J Biol Chem 1997, 272(2 I): I3772-13778.

49. Boutet I, Long Ky CL, Bonhomme F: A transcriptomic approach of salinity response in the euryhaline teleost, Dicentrarchus labrax. Gene 2006, 379:40-50.

50. Song HD, Sun XJ, Deng $M$, Zhang GW, Zhou $Y, W u X Y$, Sheng $Y$, Chen Y, Ruan Z, Jiang CL, Fan HY, Zon LI, Kanki JP, Liu TX, Look AT, Chen Z: Hematopoietic gene expression profile in zebrafish kidney marrow. Proceedings of the National Academy of Sciences of the United States of America 2004, I I I(46): 16240-I 6245

5I. Laterveer L, Lindley IJ, Heemskerk DP, Camps JA, Pauwels EK, Willemze R, Fibbe WE: Rapid mobilization of hematopoietic progenitor cells in rhesus monkeys by a single intravenous injection of interleukin-8. Blood 1996, 87(2):78|-788.

52. Van den Steen PE, Proost P, Wuyts A, Van Damme J, Opdenakker G: Neutrophil gelatinase $B$ potentiates interleukin-8 tenfold by aminoterminal processing, whereas it degrades CTAP-III, PF-4, and GRO-alpha and leaves RANTES and MCP-2 intact. Blood 2000, 96(8):2673-268।.

53. Donate C, Roher N, Balasch JC, Ribas L, Goetz FW, Planas JV, Tort $L$, Mackenzie S: CD83 expression in sea bream macrophages is 
a marker for the LPS-induced inflammatory response. Fish Shellfish Immunol 2007, 23(4):877-85.

54. Ohta Y, Landis E, Boulay T, Phillips RB, Collet B, Secombes CJ, Flajnik MF, Hansen JD: Homologs of CD83 from elasmobranch and teleost fish. J Immunol 2004, I 73(7):4553-4560.

55. Jimenez N, Coll J, Salguero FJ, Tafalla C: Co-injection of interleukin 8 with the glycoprotein gene from viral haemorrhagic septicemia virus (VHSV) modulates the cytokine response in rainbow trout (Oncorhynchus mykiss). Vaccine 2006, 24(2728):56|5-5626.

56. Tafalla C, Coll J, Secombes CJ: Expression of genes related to the early immune response in rainbow trout (Oncorhynchus mykiss) after viral haemorrhagic septicemia virus (VHSV) infection. Dev Comp Immunol 2005, 29(7):615-626.

57. Triantafilou K, Triantafilou M, Dedrick RL: A CDI4-independent LPS receptor cluster. Nature immunology 200I, 2(4):338-345.

58. Levesque JP, Hendy J, Takamatsu Y, Simmons PJ, Bendall LJ: Disruption of the CXCR4/CXCLI 2 chemotactic interaction during hematopoietic stem cell mobilization induced by GCSF or cyclophosphamide. The Journal of clinical investigation 2003, I I I(2):187-196.

59. Johnson MC, Sangrador-Vegas A, Smith TJ, Cairns MT: Molecular cloning and expression analysis of rainbow trout (Oncorhynchus mykiss) matrix metalloproteinase-9. Fish Shellfish Immunol 2004, I 7(5):499-503.

60. Takeuchi K, Kubota S, Kinoshita M, Toyohara H, Sakaguchi M: Cloning and characterization of cDNA for carp matrix metalloproteinase 9. Fisheries Sci 2002:610-617.

61. Muller CS, Huff T, Hannappel E: Reduction of thymosin beta4 and actin in HL60 cells during apoptosis is preceded by a decrease of their mRNAs. Molecular and cellular biochemistry 2003, 250(I-2): I79-188.

62. Huff T, Muller CS, Otto AM, Netzker R, Hannappel E: beta-Thymosins, small acidic peptides with multiple functions. The international journal of biochemistry \& cell biology 200I, 33(3):205-220.

63. Sun HQ, Yin HL: The \{beta\}-Thymosin Enigma. Ann N Y Acad Sci 2007, I I I 2:45-55.

64. Lovoll M, Dalmo RA, Bogwald J: Extrahepatic synthesis of complement components in the rainbow trout (Oncorhynchus mykiss). Fish Shellfish Immunol 2007, 23(4):72I-3I.

65. Laufer J, Katz Y, Passwell JH: Extrahepatic synthesis of complement proteins in inflammation. Molecular immunology 200I, 38(2-3):22।-229.

66. Nakao M, Kajiya T, Sato Y, Somamoto T, Kato-Unoki Y, Matsushita M, Nakata M, Fujita T, Yano T: Lectin pathway of bony fish complement: identification of two homologs of the mannosebinding lectin associated with MASP2 in the common carp (Cyprinus carpio). J Immunol 2006, I77(8):547I-5479.

67. Nakao M, Osaka K, Kato Y, Fujiki K, Yano T: Molecular cloning of the complement (CIr/CIs/MASP2-like serine proteases from the common carp (Cyprinus carpio). Immunogenetics 200I, 52(3-4):255-263

68. Lovoll M, Fischer U, Mathisen GS, Bogwald J, Ototake M, Dalmo RA The $C 3$ subtypes are differentially regulated after immunostimulation in rainbow trout, but head kidney macrophages do not contribute to C3 transcription. Veterinary immunology and immunopathology 2007, II 7(3-4):284-295.

69. Ratajczak J, Reca R, Kucia M, Majka M, Allendorf DJ, Baran JT, Janowska-Wieczorek A, Wetsel RA, Ross GD, Ratajczak MZ: Mobilization studies in mice deficient in either $\mathrm{C} 3$ or $\mathrm{C} 3 \mathrm{a}$ receptor $(\mathrm{C} 3 \mathrm{aR})$ reveal a novel role for complement in retention of hematopoietic stem/progenitor cells in bone marrow. Blood 2004, I03(6):207|-2078.

70. Ratajczak MZ, Reca R, Wysoczynski M, Kucia M, Baran JT, Allendorf DJ, Ratajczak J, Ross GD: Transplantation studies in C3-deficient animals reveal a novel role of the third complement component (C3) in engraftment of bone marrow cells. Leukemia 2004, 18(9): 1482-1490.

7I. Reca R, Mastellos D, Majka M, Marquez L, Ratajczak J, Franchini S, Glodek A, Honczarenko M, Spruce LA, Janowska-Wieczorek A, Lambris JD, Ratajczak MZ: Functional receptor for C3a anaphylatoxin is expressed by normal hematopoietic stem/ progenitor cells, and $\mathrm{C} 3 \mathrm{a}$ enhances their homing-related responses to SDF-I. Blood 2003, I0I(I0):3784-3793.

72. Botelho RJ, Hackam DJ, Schreiber AD, Grinstein S: Role of COPI in Phagosome Maturation. J Biol Chem 2000, 275(2 I):15717-I5727.
73. Nakanishi T, Fischer U, Dijkstra JM, Hasegawa S, Somamoto T, Okamoto N, Ototake M: Cytotoxic T cell function in fish. Dev Comp Immunol 2002, 26(2): I3I-139.

74. Dijkstra JM, Somamoto T, Moore L, Hordvik I, Ototake M, Fischer U: Identification and characterization of a second CD4-like gene in teleost fish. Molecular immunology 2006, 43(5):4I0-4I9.

75. Moore LJ, Somamoto T, Lie KK, Dijkstra JM, Hordvik I: Characterisation of salmon and trout CD8alpha and CD8beta. Molecular immunology 2005, 42(1 0): I 225-1234.

76. Overturf K, LaPatra S: Quantitative expression (Walbaum) of immunological factors in rainbow trout, Oncorhynchus mykiss (Walbaum), after infection with either Flavobacterium psychrophilum, Aeromonas salmonicida, or infectious haematopoietic necrosis virus. J Fish Dis 2006, 29(4):2 I5-224.

77. Hansen JD, La Patra S: Induction of the rainbow trout MHC class I pathway during acute IHNV infection. Immunogenetics 2002, 54(9):654-66I.

78. Jorgensen SM, Hetland DL, Press CM, Grimholt U, Gjoen T: Effect of early infectious salmon anaemia virus (ISAV) infection on expression of MHC pathway genes and type I and II interferon in Atlantic salmon (Salmo salar L.) tissues. Fish Shellfish Immunol 2007, 23(3):

79. Zhang YX, Chen SL: Molecular identification, polymorphism, and expression analysis of major histocompatibility complex class IIA and B genes of turbot (Scophthalmus maximus). Marine biotechnology (New York, NY 2006, 8(6):6 I I-623.

80. Boudinot P, Blanco M, de Kinkelin P, Benmansour A: Combined DNA immunization with the glycoprotein gene of viral hemorrhagic septicemia virus and infectious hematopoietic necrosis virus induces double-specific protective immunity and nonspecific response in rainbow trout. Virology 1998 , 249(2):297-306.

81. Hoeger B, Kollner B, Dietrich DR, Hitzfeld B: Water-borne diclofenac affects kidney and gill integrity and selected immune parameters in brown trout (Salmo trutta f. fario). Aquatic toxicology (Amsterdam, Netherlands) 2005, 75(I):53-64.

82. Boudinot $\mathrm{P}$, Boubekeur S, Benmansour $\mathrm{A}$ : Rhabdovirus infection induces public and private $T$ cell responses in teleost fish. J Immunol 200I, 167( I I):6202-6209.

83. Matsuyama T, Fujiwara A, Nakayasu C, Kamaishi T, Oseko N, Tsutsumi N, Hirono I, Aoki T: Microarray analyses of gene expression in Japanese flounder Paralichthys olivaceus leucocytes during monogenean parasite Neoheterobothrium hirame infection. Diseases of aquatic organisms 2007, 75(I):79-83.

84. Tassakka AC, Savan $R$, Watanuki H, Sakai M: The in vitro effects of CpG oligodeoxynucleotides on the expression of cytokine genes in the common carp (Cyprinus carpio L.) head kidney cells. Veterinary immunology and immunopathology 2006, I I O(I-2):79-85.

85. Sakai M, Kono T, Savan R: Identification of expressed genes in carp (Cyprinus carpio) head kidney cells after in vitro treatment with immunostimulants. Developments in biologicals 2005 , I 21:45-5 I.

86. Rangatia J, Vangala RK, Treiber N, Zhang P, Radomska H, Tenen DG, Hiddemann W, Behre G: Downregulation of c-Jun expression by transcription factor C/EBPalpha is critical for granulocytic lineage commitment. Molecular and cellular biology 2002, 22(24):868I-8694

87. Moran ST, Cariappa A, Liu H, Muir B, Sgroi D, Boboila C, Pillai S: Synergism between NF-\{kappa\}B I/p50 and Notch2 during the Development of Marginal Zone B Lymphocytes. J Immunol 2007, I 79(I): 195-200.

88. Liu WH, Lai MZ: Deltex regulates T-cell activation by targeted degradation of active MEKKI. Molecular and cellular biology 2005 , 25(4): 1367-1378.

89. Kraal G, van der Laan LJ, Elomaa O, Tryggvason K: The macrophage receptor MARCO. Microbes and infection / Institut Pasteur 2000, 2(3):313-316

90. Bergmann SM, Fichtner D, Skall HF, Schlotfeldt HJ, Olesen NJ: Ageand weight-dependent susceptibility of rainbow trout Oncorhynchus mykiss to isolates of infectious haematopoietic necrosis virus (IHNV) of varying virulence. Diseases of aquatic organisms 2003, 55(3):205-210.

91. Quillet E, Dorson M, Le Guillou S, Benmansour A, Boudinot P: Wide range of susceptibility to rhabdoviruses in homozygous 
clones of rainbow trout. Fish Shellfish Immunol 2007, 22(5):510-519.

92. Krasnov A, Koskinen H, Rexroad C, Afanasyev S, Molsa H, Oikari A: Transcriptome responses to carbon tetrachloride and pyrene in the kidney and liver of juvenile rainbow trout (Oncorhynchus mykiss). Aquatic toxicology (Amsterdam, Netherlands) 2005, 74(I):70-8I.

93. Iwama GK, Afonso LO, Todgham A, Ackerman P, Nakano K: Are hsps suitable for indicating stressed states in fish? The Journal of experimental biology 2004, 207(Pt I): 15-19.

94. Iwama GK, McGeer JC, Pawluck MP: The effect of five fish anaesthetics on acid-base balance, hematocrit, cortisol an adrenaline in rainbow trout. Can J Zool 1989:2065-2073.

95. Chomcynski P: A reagent for the single-step simultaneous isolation of RNA, DNA and proteins from cell and tissue samples. BioTechniques 1993:532-537.

96. Chomcynski P, Sacchi N: Single step method of RNA isolation by acid guanidinium thiocyanate-phenol-chloroform extraction. Anal Biochem 1987, 162(1):156-169.

97. Tomasec J, Fijan N: Virusne bolestiriba (viral dseases of fish). Final report on research under a part of project 6n/l966, Zagreb I97I.

98. Reed LJ, Muench H: A simple method of estimating fifty percent endpoints. The American Journal of Hygiene 1938, 27:493-497.

99. Yang YH, Speed T: Design issues for CDNA microarray experiments. Nature reviews 2002, 3(8):579-588.

100. Cleveland WS Grosse, E., Shyu, W.M.: Local regression models. In Statistical Models Edited by: J.M. Chambers TJHE. S, Pacific Grove, Wadsworth and Brooks/Cole; 1999:309-376.

I0I. Storey JD, Tibshirani R: Statistical significance for genomewide studies. Proceedings of the National Academy of Sciences of the United States of America 2003, I 00( I 6):9440-9445.

102. Ashburner M, Ball CA, Blake JA, Botstein D, Butler H, Cherry JM, Davis AP, Dolinski K, Dwight SS, Eppig JT, Harris MA, Hill DP, IsselTarver L, Kasarskis A, Lewis S, Matese JC, Richardson JE, Ringwald M, Rubin GM, Sherlock G: Gene ontology: tool for the unification of biology. The Gene Ontology Consortium. Nat Genet 2000, 25(I):25-29.

\section{Publish with Bio Med Central and every scientist can read your work free of charge}

"BioMed Central will be the most significant development for disseminating the results of biomedical research in our lifetime. "

Sir Paul Nurse, Cancer Research UK

Your research papers will be:

- available free of charge to the entire biomedical community

- peer reviewed and published immediately upon acceptance

- cited in PubMed and archived on PubMed Central

- yours - you keep the copyright

Submit your manuscript here:

http://www.biomedcentral.com/info/publishing_adv.asp
BioMedcentral 